This article was downloaded by: [University of North Carolina Charlotte]

On: 04 October 2012, At: 08: 29

Publisher: Routledge

Informa Ltd Registered in England and Wales Registered Number: 1072954 Registered office: Mortimer House, 37-41 Mortimer Street, London W1T 3J H, UK

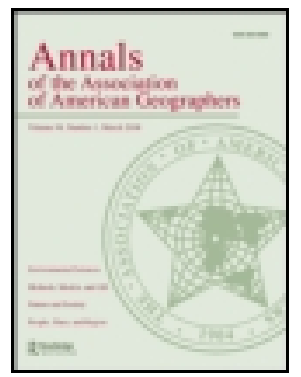

\title{
Annals of the Association of American Geographers
}

Publication details, including instructions for authors and subscription information:

http:// www.tandfonline.com/loi/ raag20

\section{FUTURES: Multilevel Simulations of Emerging Urban-Rural Landscape Structure Using a Stochastic Patch-Growing Algorithm}

\author{
Ross K. Meentemeyer ${ }^{a}$, Wenwu Tang ${ }^{a}$, Monica A. Dorning ${ }^{a}$, J ohn B. Vogler ${ }^{a}$, Nik J . \\ Cunniffe ${ }^{b} \&$ Douglas A. Shoemaker ${ }^{a}$ \\ ${ }^{a}$ Department of Geography and Earth Sciences, University of North Carolina at Charlotte \\ ${ }^{\mathrm{b}}$ Department of Plant Sciences, University of Cambridge \\ Version of record first published: 04 Oct 2012.
}

To cite this article: Ross K. Meentemeyer, Wenwu Tang, Monica A. Dorning, J ohn B. Vogler, Nik J. Cunniffe \& Douglas A. Shoemaker (2012): FUTURES: Multilevel Simulations of Emerging Urban-Rural Landscape Structure Using a Stochastic PatchGrowing Algorithm, Annals of the Association of American Geographers, DOI: 10.1080/ 00045608.2012. 707591

To link to this article: http:// dx.doi.org/ 10.1080/00045608.2012.707591

\section{(iFirst}

\section{PLEASE SCROLL DOWN FOR ARTICLE}

Full terms and conditions of use: http://www.tandfonline.com/page/terms-and-conditions

This article may be used for research, teaching, and private study purposes. Any substantial or systematic reproduction, redistribution, reselling, loan, sub-licensing, systematic supply, or distribution in any form to anyone is expressly forbidden.

The publisher does not give any warranty express or implied or make any representation that the contents will be complete or accurate or up to date. The accuracy of any instructions, formulae, and drug doses should be independently verified with primary sources. The publisher shall not be liable for any loss, actions, claims, proceedings, demand, or costs or damages whatsoever or howsoever caused arising directly or indirectly in connection with or arising out of the use of this material. 


\title{
FUTURES: Multilevel Simulations of Emerging Urban-Rural Landscape Structure Using a Stochastic Patch-Growing Algorithm
}

\author{
Ross K. Meentemeyer,* Wenwu Tang,* Monica A. Dorning,* John B. Vogler,* Nik J. Cunniffe, ${ }^{\dagger}$ \\ and Douglas A. Shoemaker* \\ *Department of Geography and Earth Sciences, University of North Carolina at Charlotte \\ 'Department of Plant Sciences, University of Cambridge
}

We present a multilevel modeling framework for simulating the emergence of landscape spatial structure in urbanizing regions using a combination of field-based and object-based representations of land change. The FUTure Urban-Regional Environment Simulation (FUTURES) produces regional projections of landscape patterns using coupled submodels that integrate nonstationary drivers of land change: per capita demand, site suitability, and the spatial structure of conversion events. Patches of land change events are simulated as discrete spatial objects using a stochastic region-growing algorithm that aggregates cell-level transitions based on empirical estimation of parameters that control the size, shape, and dispersion of patch growth. At each time step, newly constructed patches reciprocally influence further growth, which agglomerates over time to produce patterns of urban form and landscape fragmentation. Multilevel structure in each submodel allows drivers of land change to vary in space (e.g., by jurisdiction), rather than assuming spatial stationarity across a heterogeneous region. We applied FUTURES to simulate land development dynamics in the rapidly expanding metropolitan region of Charlotte, North Carolina, between 1996 and 2030, and evaluated spatial variation in model outcomes along an urban-rural continuum, including assessments of cell- and patch-based correctness and error. Simulation experiments reveal that changes in per capita land consumption and parameters controlling the distribution of development affect the emergent spatial structure of forests and farmlands with unique and sometimes counterintuitive outcomes. Key Words: fragmentation, land change model, nonstationarity, object-based, region growing algorithm.

我们将运用结合基于场域和基于对象的土地变迁再现, 提出一个模拟都市化区域浮现的地景空间结构的多重层级模 式化架构。未来都市 - 区域环境模拟系统 (FUTURES), 透过运用整合土地变迁非固定趋力一人均需求、地点适宜 性和变迁事件的空间结构的耦合子模型, 生产地景模式的区域投影。我们运用随机区域成长演算法, 该演算法根据 对于控制嵌块体成长的大小、形态与分散参数的经验评估, 聚集网格层级的转变, 将土地变迁事件的嵌块体模拟为 分离的空间对象模组。在每个时间步骤中, 新建构的嵌块体将反馈影响未来的成长, 并随着时间凝聚形成都市形态 与碎裂的地景。各子模型中的多重层级结构, 容许土地变迁趋力的空间变化 (例如根据管辖区域), 而非假定异质区 域中的空间不变性。我们运用 FUTURES 系统, 模拟北加州夏洛特快速扩张的都会区于 1996 年至 2030 年间的土 地发展动态, 并随着一处城 - 乡连续带评估模型结果中的空间变异, 包含衡量以网格为基础和以嵌块体为基础的正确 与错误。模拟实验揭露了人均土地消费的改变以及控制发展分布的参数, 将影响浮现中的森林与农田空间结构, 并 有着特殊且有时是违反直觉的结果。关键词: 碎裂化, 土地变迁模型, 非僵固化, 基于对象, 区域成长演算法。

Utilizando una combinación de representaciones de cambios de la tierra basadas en campo y objeto, presentamos un marco de modelización de nivel múltiple para simular cómo surge la estructura espacial del paisaje en regiones en proceso de urbanización. La Simulación Ambiental Urbano-Regional FUTure (FUTURES) produce proyecciones regionales de patrones paisajistas con el uso de sub-modelos acoplados que integran controles no estacionarios de cambios de la tierra: demanda per cápita, idoneidad del sitio y la estructura espacial de eventos de conversión. Los parches que representan eventos de cambios de la tierra se simulan como objetos espaciales discretos utilizando un algoritmo estocástico de acrecentamiento regional que añade transiciones a nivel de celda con base en estimativos empíricos de los parámetros que controlan el tamaño, forma y dispersión del crecimiento del parche. En cada etapa temporal, los nuevos parches construidos influencian recíprocamente el crecimiento adicional, el cual se aglomera con el tiempo para producir patrones de morfología urbana y fragmentación del 
paisaje. La estructura de nivel múltiple en cada sub-modelo permite que los determinadores de cambios de la tierra varíen en el espacio (por ejemplo, por jurisdicción), en vez de asumir estacionalidad espacial a través de una región heterogénea. Aplicamos FUTURES para simular la dinámica del desarrollo de la tierra en la región metropolitana de Charlotte, Carolina del Norte, en rápida expansión, entre 1996 y 2030, y evaluamos la variación espacial en los resultados del modelo sobre un continuo urbano-rural, incluyendo las estimaciones de propiedad y error en los contextos de celda y parche. Los experimentos de simulación revelan que los cambios en el consumo de tierra per cápita y los parámetros que controlan la distribución del desarrollo afectan la emergente estructura espacial de bosques y tierras de cultivo, con resultados singulares y a veces contra-intuitivos. Palabras clave: fragmentación, modelo de cambio de la tierra, no estacionalidad, basado en objeto, algoritmo de acrecentamiento regional.

$\mathrm{E}$ ach year societies worldwide are demanding more developed land on a per capita basis (United $\mathrm{Na}$ tions Population Fund 2007). This trend is especially common in rapidly urbanizing regions, where conversion of forests and farmlands to built land uses has compromised the sustainability and resilience of local ecosystems and the resources they provide (Brown, Johnson, et al. 2005; Radeloff, Hammer, and Stewart 2005; Berke et al. 2006). The natural amenities that once fostered nascent urban economies, such as the availability of clean water, rich farmlands, and productive forests, are being exhausted by more than half of the world's population, whose demands for these same essential resources must now be filled by costly surrogates (Wackernagel et al. 1999). In most metropolitan regions, effects of urban sprawl are accelerating with little sign of embracing alternative futures for urban growth (Ewing, Pendall, and Chen 2002; Downs 2005).

The dispersion of low-density and "leapfrog" development—characteristic of rapidly urbanizing regions-dissects natural landscapes into highly fragmented patches (Radeloff, Hammer, and Stewart 2005; Irwin and Bockstael 2007). Changes in the size, shape, and connectivity of human-modified landscapes can dramatically affect ecological processes by disrupting exchanges of energy and matter (M. G. Turner 1989; Alberti 2005). The spatial structure of urbanizing landscapes is also critical to the provision of ecosystem services (Lovell and Johnston 2009; Alberti 2010). For example, landscape configuration influences biodiversity (Gagné and Fahrig 2011) by altering dispersal (Damschen et al. 2008) and spread of exotic species (With 2002); impacts water quality and flood risk in response to additions of impervious surfaces and sources of pollution (Arnold and Gibbons 1996); and contributes to local- and regional-scale climate changes through heat island effects (Arnfield 2003), anthropogenic emissions (Weathers, Cadenasso, and Pickett 2001), and reduced carbon sequestration (D. T. Robinson, Brown, and Currie 2009).
Simulation models are increasingly used to project impacts of land change trajectories on urban form and landscape fragmentation, but replicating the dynamic and inherently spatial nature of landscape changes in regional urban-rural systems continues to challenge simulation models (Pontius, Cornell, and Hall 2001). Herold, Couclelis, and Clarke (2005) asserted that predicting socio-ecological impacts of land change dynamics will be possible only when models are capable of simulating realistic spatial structures of development outcomes at local to landscape scales. The degree to which spatial structure is replicated in land change projections is often evaluated a posteriori to assess model performance or to quantify patterns of fragmentation and sprawl (e.g., Aguilera, Valenzuela, and BotequilhaLeitão 2011). Less emphasis has been placed on incorporating algorithms specifically intended to simulate spatial structure of land change and resultant fragmentation. Notable examples are Brown et al. (2002) and Jenerette and Wu (2001), who incorporated spatial patterns of landscape change into models a priori using semivariograms and a genetic algorithm. Models that rely on cell-level state transitions (including cellular automata and agent-based approaches), however, continue to struggle to generate realistic spatial structures at relevant ecological and decision-making scales (Jantz and Goetz 2005; Yeh and Li 2006). This perhaps illustrates the paradox between land change manifested as discrete conversion events (or objects) and representations of change using raster cells-an arbitrary spatial unit - that are unlikely to coincide with the spatial structure of conversion. Accordingly, approaches are needed that bridge cell- and object-based representations in land change modeling.

The presence of spatial nonstationarity-a condition that occurs when processes differ across space-poses another challenge to simulating land use change across large, heterogeneous regions (Munroe and Müller 2007; Sohl et al. 2010). Regional models that concentrate on global processes of a system, assuming stationarity, often 
fail to capture variation that occurs at subregional levels (B. L. Turner, Lambin, and Reenberg 2007; Verburg and Overmars 2009). Methods designed to address spatially varying processes have been explored in simulations of land change, such as using heuristics (F. Wu 2002) and by developing separate models for each subregion ( $\mathrm{Li}$, Yang, and Liu 2008). Multilevel statistical approaches might offer a more objective and efficient option to simultaneously account for global and local trends by allowing hypothesized relationships between land use and explanatory factors to vary across a region, thereby minimizing assumptions of spatial stationarity (Pan and Bilsborrow 2005; Overmars and Verburg 2006). The ability of multilevel approaches to help account for immeasurable processes at multiple scales (Verburg et al. 2004) will also move us closer to developing multiscale simulations of land change-a key requirement of a comprehensive land change modeling framework (Irwin, Jayaprakash, and Munroe 2009).

In this article, we describe a multilevel modeling framework for simulating the emergence of landscape spatial structure in urbanizing regions using a combination of field-based and object-based representations of land change. The FUTure Urban-Regional Environment Simulation (FUTURES) couples submodels of three key drivers of land change: per capita demand, site suitability, and the spatial structure of conversion events. Discrete patches of land change events are simulated using a stochastic region growing algorithm that aggregates cell-level transitions based on empirical estimation of parameters that control the size, shape, and dispersion of patch growth (Figure 1). Multilevel structure in each submodel allows drivers of land change to vary in space (e.g., by jurisdiction), rather than assuming spatial stationarity across a heterogeneous region. We calibrated FUTURES in the rapidly growing metropolitan region of Charlotte, North Carolina, and assessed the framework's ability to simulate spatial complexity along the urban-rural continuum using cell- and patch-based metrics of correctness and error (Chen and Pontius 2010). Charlotte sits in the middle of the "Char-lanta" megalopolis, a biologically diverse and productive region that still supports substantial forest and agricultural resources (Figure 2). We used Charlotte as a case study of fast-growing urban regions in the developed world to explore feedbacks between alternative scenarios of growth and fragmentation of natural and agricultural landscapes through the year 2030 in anticipation of FUTURES being deployed as a multijurisdictional, spatial decision support tool.

\section{Simulation Framework}

\section{Overview}

FUTURES is a land change modeling framework made up of three interacting submodels (Figure 1) that accommodates multilevel drivers of land change across a heterogeneous region. The POTENTIAL submodel quantifies the development potential of a cell based on multilevel relationships between land change and hypothesized environmental, infrastructural, and socioeconomic factors; DEMAND quantifies differences in per capita land demand among subregions based on increases in population concurrent with the rate of development specific to each subregion or level; and PGA is a stochastic patch-growing algorithm that bridges field-based and object-based representations of change by constructing discrete land conversion events prescribed by DEMAND from cell-level state transitions on the POTENTIAL surface. At each time step, newly constructed objects reciprocally influence further growth, which agglomerates over time to produce spatial patterns of urban form and landscape fragmentation.

\section{POTENTIAL: Multilevel Gradients of Development Suitability}

The POTENTIAL submodel uses site suitability modeling approaches to quantify spatial gradients of land development potential or likelihood based on multilevel relationships between observed change and the socioeconomic, infrastructural, and environmental dimensions of a region. The model uses multilevel logistic regression to (1) account for hierarchical characteristics of the land use system (Verburg et al. 2004), including variation among jurisdictional structures that might reflect policies that are otherwise difficult to quantify; (2) improve the description of land use choices (Pan and Bilsborrow 2005; Overmars and Verburg 2006); and (3) account for divergent relationships between predictor and response variables (Gelman and Hill 2007). In FUTURES, levels are defined subregionally (e.g., a county or census tract) to consider variation in relationships according to spatial context and processes acting at multiple scales (Jones and Duncan 1996; Fotheringham and Brunsdon 1999). This spatial classification addresses nonstationary processes that occur across discrete regional boundaries and is therefore particularly useful to account for jurisdictional policy effects (Fotheringham and Brunsdon 1999). Integration of 


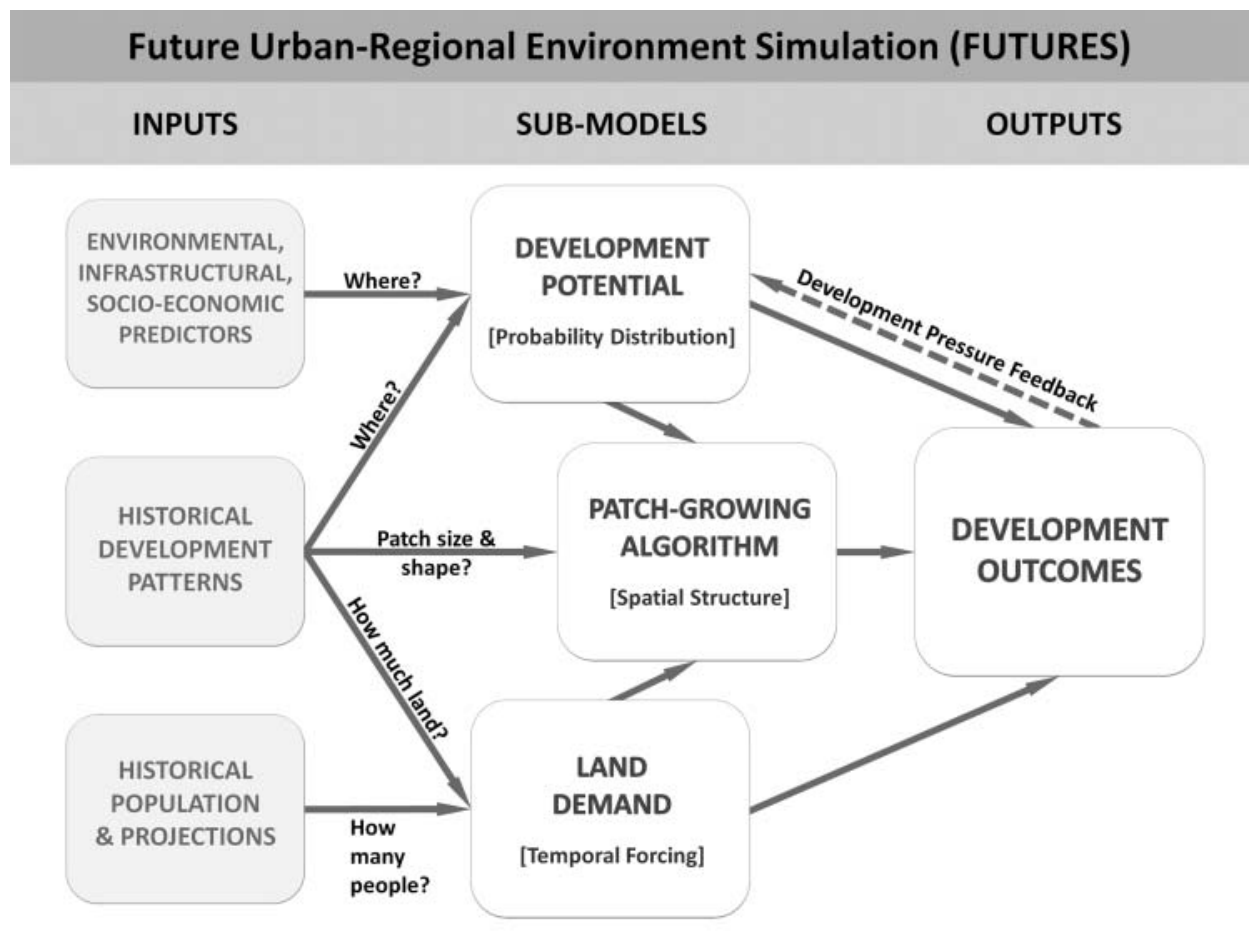

Figure 1. The FUTURES land change modeling framework.

spatially and temporally explicit factors, including positive feedbacks that estimate the influence of new and extant land development on future change (development pressure; see Equation 2), allows POTENTIAL to model dynamic probability gradients of land change that underpin regional growth patterns and provide a "playing field" on which FUTURES simulates land change (Figure 3A).



Figure 2. The Charlotte Metropolitan region located within (A) the "Char-lanta" megalopolis in the Southeastern United States. (B) The study system gained 8.3 percent developed land between 1996 and 2006 and was 24 percent developed by 2006 with substantial remaining tracts of forest and farmland. (C) Cabarrus County (FUTURES calibration site) exhibits a clear urban-rural gradient with growth rates and patterns representative of the study system. (Color figure available online.) 

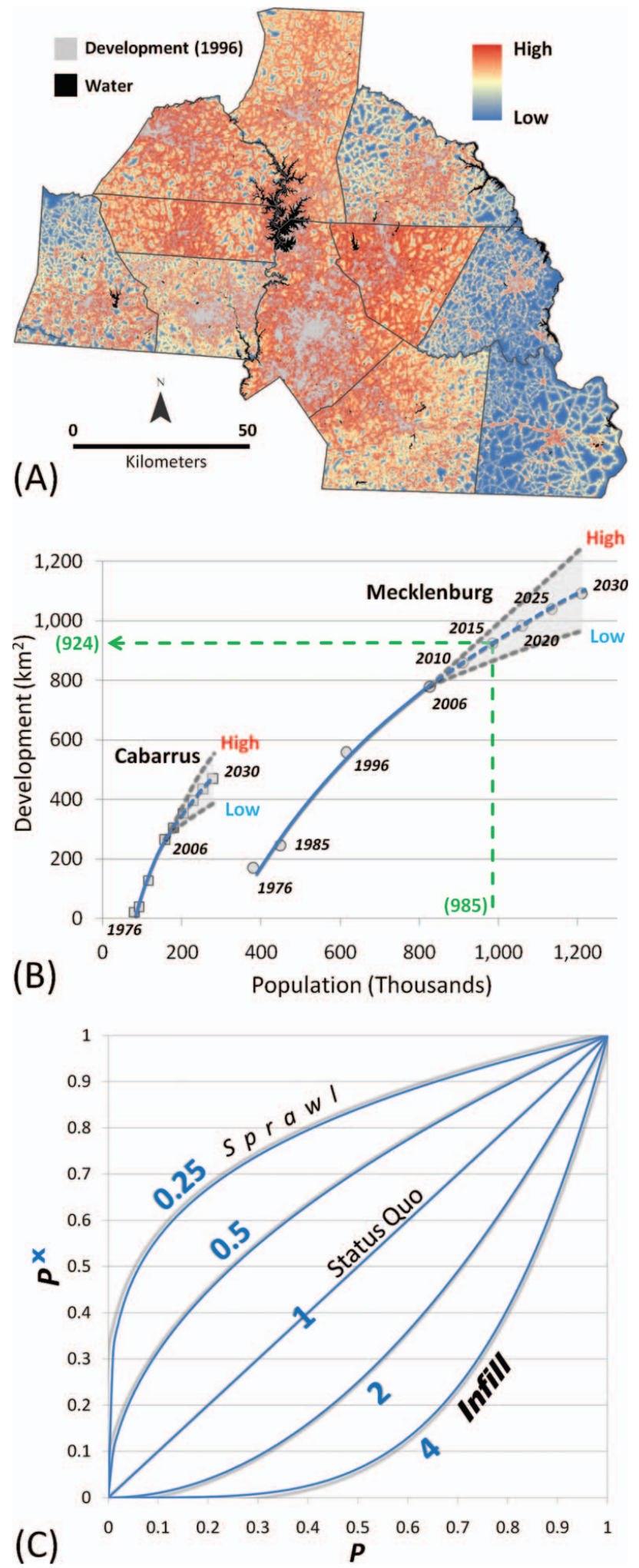

Figure 3. (A) Spatially explicit surface of the development potential submodel (POTENTIAL) ranges from high (red) to low (blue) development likelihood. Gray denotes development as of 1996. (B) County-level forecasts of per capita land consumption (DEMAND). Status quo trendlines are shown in blue. Gray dashed lines denote alternative scenarios of land consumption. (C) Range of power functions (INCENTIVES) for transforming the development potential $(P)$ surface. (Color figure available online.)

\section{DEMAND: Per Capita Demand for Development by Level}

DEMAND estimates the rate of per capita land consumption specific to each subregion or level (e.g., Figure 3B). Forecasts of land consumption are based on extrapolations between historical changes in population and land conversion given expected or hypothetical scenarios of future population growth. Either prescribed or statistical approaches can be used to construct the per capita demand relationship for any level of population aggregation (e.g., county, census tract, census block), depending on the user's preferred level of observation or data availability. Inputs for land area converted over a given time interval can be obtained through change analysis of existing maps (e.g., National Land Cover Dataset) or custom analysis of remote sensing data (see the section "Remote Sensing of Land Change" later in this article). Projections of land consumption at subregional extents reduce assumptions of stationarity and prescribe how much land to convert at a given time step.

\section{PGA: Patch-Growing Algorithm}

The PGA is a stochastic simulation that maps the allocation and spatial structure of land change using iterative site selection and a contextually aware region growing mechanism that changes cells from "undeveloped" to terminal "developed" states. PGA constructs conversion event objects by combining cell- and objectbased representations of land change. Developed cells organize themselves over time into new patches of prescribed sizes and shapes, which can further aggregate into superpatches. Simulations of change at each time step feed development pressure back to the POTENTIAL submodel, influencing site suitability. Proxies for nonrationalities or human agency enter PGA as stochastic elements (García et al. 2011) that influence both site selection and patch configuration.

For a given time interval, patches are constructed in three steps. First, a seed for the initiation of a patch is allocated randomly across the POTENTIAL probability gradient. Using a Monte Carlo approach, this seed survives if the probability value in POTENTIAL is larger than a random number $(0-1)$. Allocation and selection processes are repeated until a seed survives and its resident cell is selected to convert. Second, PGA examines the POTENTIAL suitability of contiguous cells and the spatial context of the cells in relation to the seed cell using a four-neighbor search rule. The inclusion of a cell (cell $i$ ) within a growing patch is determined 
by a composite suitability score, denoted as $s_{i}$ in Equation 1.

$$
s_{i}=s_{i}^{\prime} * d^{-\alpha}
$$

where $s_{i}^{\prime}$ is the underlying development potential of the cell in question, $d$ is its distance from the seed cell, and $\alpha$ is an adjustable scaling factor that controls patch compactness through a distance decay effect - that is, $\alpha$ in this equation is the parameter of patch compactness. As $\alpha$ increases, cells closer to the initial seed become relatively more attractive, promoting compact patch production. The composite score of each cell is then listed and ranked for each candidate neighbor cell. Third, PGA uses these ranked candidate cells to guide the neighborhood search for further patch growth; this process continues until a stopping criterion is met, such as patch size or total composite score (which can be informed by data on historical development), and the aggregate, contiguous cells are converted to a "changed" state. Conversion trajectory is assumed to be unidirectional: Once a cell is converted it remains in a static developed state. PGA continues to allocate patches until the per capita land DEMAND for growth is satisfied. The PGA approach provides a stochastic alternative to deterministic region-growing algorithms often used in site selection and conservation planning (Church et al. 2003).

Development pressure is a dynamic spatial variable derived from the patch-building process of PGA and associated with the POTENTIAL submodel. It is used to estimate the influence of surrounding land development on the likelihood that a cell changes states. The development pressure (noted as $p_{i}^{\prime}$ in Equation 2) on cell $i$ is given by:

$$
p_{i}^{\prime}=\sum_{k=1}^{n_{i}} \text { State }_{k} / d_{i k}^{\gamma}
$$

where State $_{k}$ is a binary variable that indicates whether the $k$ th neighboring cell is developed (1) or undeveloped ( 0$), d_{i k}$ is the distance between the $k$ th neighboring cell and the current cell $i, \gamma$ is a coefficient that controls the influence of distance between neighboring cells and cell $i$, and $n_{i}$ is the number of neighboring cells within a specific range with respect to cell $i$. Assuming the influence of a neighboring developed cell on the current cell is distance-decayed, the development pressure on an undeveloped cell is a function of neighboring developed cells and the distance between these cells and the cell in question. At each time step, PGA updates the POTENTIAL probability gradient as land change events occur, and the new development pressure in turn affects future land change in a path-dependent manner with positive feedbacks (Brown, Page, et al. 2005). Because stochastic path-dependent systems are sensitive to initial conditions (Brown, Page, et al. 2005), we programmed PGA to produce multiple outcomes from a series of independent runs with model performance metrics reported as mean values.

User-set parameters within the PGA submodel allow FUTURES to be calibrated for accuracy and used to explore alternative futures of urbanization and landscape fragmentation (Table 1). For example, the patch compactness parameter (i.e., $\alpha$ in Equation 1) allows a user to control the spatial complexity of patch shapes produced during the region growing process by influencing the amount of exploration in the neighborhood search mechanism. Scenarios involving policies that encourage infill versus sprawl can be explored using the incentive parameter, which uses a power function to transform the evenness of the probability gradient in POTENTIAL (Figure 3C). This transformation allows users to increase or decrease the likelihood of land change by altering site suitability in planning scenarios. The degree to which incentive transforms urban form and patterns of landscape fragmentation is assessed in our application of FUTURES later.

\section{Model Application}

We used FUTURES to project scenarios of land change in the metropolitan region of Charlotte, North Carolina, between 2006 and 2030. We first describe the methodologies that enable FUTURES to produce projections of forest and farmland conversion given a continuation of historical trends, including our data selection, analytical approaches, and calibration procedures. We then evaluated FUTURES's performance in simulating change between 1996 and 2006 using cellbased metrics of error due to quantity and error due to allocation (Chen and Pontius 2010) and patch-based metrics of spatial structure along an urban-rural gradient. We conclude with three simulation experiments designed to demonstrate the capability of FUTURES to analyze alternative futures of urban form and landscape fragmentation.

\section{Study System}

Located in the middle of the "Char-lanta" megalopolis, the third largest megaregion in the United States 
Table 1. FUTURES submodel parameters

\begin{tabular}{|c|c|c|c|c|c|c|}
\hline \multirow{2}{*}{$\frac{\text { Submodel }}{\text { Potential }}$} & \multicolumn{2}{|c|}{ Parameter } & \multirow{2}{*}{$\begin{array}{l}\text { Description } \\
\text { Lands designated as forest } \\
\text { or farmland }\end{array}$} & \multirow{2}{*}{$\begin{array}{l}\text { Base data } \\
\text { LiDAR vegetation } \\
\text { height; Landsat } \\
\text { TM imagery }\end{array}$} & \multirow{2}{*}{$\begin{array}{c}\text { Year(s) } \\
1996,2006\end{array}$} & \multirow{2}{*}{$\begin{array}{l}\text { Data source } \\
\text { Charlotte- } \\
\text { Mecklenburg } \\
\text { County Storm } \\
\text { Water Services; } \\
\text { USGS }\end{array}$} \\
\hline & Environmental & Forest-farmland & & & & \\
\hline & & Open space & $\begin{array}{l}\text { Proximity to protected } \\
\text { open space }\end{array}$ & $\begin{array}{l}\text { Lands managed for } \\
\text { conservation and } \\
\text { open space }\end{array}$ & 1996, 2006 & Conservision-NC \\
\hline & & Topography & 1. Elevation & $\begin{array}{l}\text { 1-arc second } \\
\text { National } \\
\text { Elevation } \\
\text { Dataset }\end{array}$ & 2006 & USGS \\
\hline & & Hydrography & $\begin{array}{l}\text { 2. Slope } \\
\text { Proximity to water bodies }\end{array}$ & $\begin{array}{l}\text { Rivers, recreational } \\
\text { lakes, and } \\
\text { reservoirs }\end{array}$ & 1996, 2006 & NC OneMap ${ }^{a}$ \\
\hline & Infrastructural & Accessibility & 1. Proximity to roads & $\begin{array}{l}\text { Primary and } \\
\text { secondary road } \\
\text { networks }\end{array}$ & 1996 & NCDOT \\
\hline & & & $\begin{array}{l}\text { 2. Proximity to } \\
\text { interchanges } \\
\text { 3. Density of roads } \\
\text { 4. Travel cost (time) }\end{array}$ & & & \\
\hline & & Municipal centers & $\begin{array}{l}\text { Proximity to } \\
\text { municipalities }\end{array}$ & $\begin{array}{l}\text { Locations of cities, } \\
\text { towns, and other } \\
\text { municipalities }\end{array}$ & 1996 & U.S. Census \\
\hline & & Water and sewer & $\begin{array}{l}\text { Proximity to water and } \\
\text { sewer service lines }\end{array}$ & $\begin{array}{l}\text { Water Services } \\
\text { Assessment } \\
\text { database }\end{array}$ & 1996 & Conservision-NC \\
\hline & Socioeconomic & Age and income & $\begin{array}{l}\text { Age/income structure and } \\
\text { distribution }\end{array}$ & Census statistics & 1996 & U.S. Census \\
\hline & & $\begin{array}{l}\text { Employment } \\
\text { attraction }\end{array}$ & $\begin{array}{l}\text { Proximity to urban } \\
\text { centers weighted by } \\
\text { number of jobs } \\
\text { provided }\end{array}$ & $\begin{array}{l}\text { Traffic analysis } \\
\text { zone (TAZ) and } \\
\text { place-of-work } \\
\text { statistics }\end{array}$ & 1996 & U.S. Census \\
\hline & & Multilevel structure & $\begin{array}{l}\text { Proxy for varying policy } \\
\text { effects }\end{array}$ & $\begin{array}{l}\text { Census statistical } \\
\text { geographies }\end{array}$ & 1996 & U.S. Census \\
\hline & Dynamic & $\begin{array}{l}\text { Development } \\
\text { pressure }\end{array}$ & $\begin{array}{l}\text { Number of neighboring } \\
\text { developed cells within } \\
\text { search distance and } \\
\text { weighted by distance }\end{array}$ & $\begin{array}{l}\text { Historical and } \\
\text { forecast } \\
\text { development } \\
\text { patterns }\end{array}$ & $1996-2030$ & $\begin{array}{l}\text { Remote sensing } \\
\quad \text { and simulations }\end{array}$ \\
\hline \multirow[t]{2}{*}{ Demand } & & Population & $\begin{array}{l}\text { Historical population and } \\
\text { projections }\end{array}$ & $\begin{array}{l}\text { State demographic } \\
\text { data }\end{array}$ & $\begin{array}{l}\text { 1976, 1985, } \\
1996-2030\end{array}$ & NCOSBM \\
\hline & & Development & Area of developed land & $\begin{array}{l}\text { Landsat MSS \& } \\
\text { TM imagery }\end{array}$ & $\begin{array}{l}1976,1985 \\
1996,2006\end{array}$ & USGS \\
\hline \multirow{3}{*}{$\begin{array}{l}\text { Patch-growing } \\
\text { algorithm }\end{array}$} & & & & $\underline{\text { Parameter range }}$ & & \\
\hline & & & $\begin{array}{l}\text { Controls area of each new } \\
\text { development patch }\end{array}$ & $\begin{array}{l}\text { Area } \geq 0.09 \text { ha } \\
\text { total region area }\end{array}$ & & \\
\hline & & Patch compactness & $\begin{array}{l}\text { Controls shape } \\
\text { complexity of each new } \\
\text { development patch }\end{array}$ & Shape $\geq 1$, no limit & & \\
\hline
\end{tabular}


Table 1. FUTURES submodel parameters (Continued)

\begin{tabular}{|c|c|c|c|c|c|}
\hline Submodel & Parameter & Description & Base data & Year(s) & Data source \\
\hline & Incentive & $\begin{array}{l}\text { Power transformation } \\
\text { of probability surface }\end{array}$ & $\begin{array}{l}\text { Incentive }>0 \text {, no } \\
\quad \text { limit }\end{array}$ & & \\
\hline & Time step & $\begin{array}{l}\text { Time interval over } \\
\text { simulation period }\end{array}$ & $\begin{array}{l}\text { Time step } \geq 1, \\
\text { simulation } \\
\text { period }\end{array}$ & & \\
\hline & Stochasticity & $\begin{array}{l}\text { Controls degree of } \\
\text { random allocation of } \\
\text { new seeds of } \\
\text { development }\end{array}$ & $0-1$ & & \\
\hline
\end{tabular}

Note: LiDAR = light detection and ranging; USGS = United States Geological Survey (www.usgs.gov); Conservision-NC = One NC Naturally's Conservation Planning Tool (www.conservision-nc.net); NCDOT = North Carolina Department of Transportation (www.ncdot.org); U.S. Census = United States Census Bureau (www.census.gov); NCOSBM = State Demographics Branch of the North Carolina Office of State Budget and Management (http://www.osbm.state.nc.us/).

aNorth Carolina ONEmap is distributed by the North Carolina Center for Geographic Information \& Analysis (www.nconemap.com).

bLandsat satellite image analysis and FUTURES simulations.

(Florida, Gulden, and Mellander 2008; see Figure 2A), Charlotte is a rapidly growing metropolitan area and the major economic hub for the eleven-county, $13,400 \mathrm{~km}^{2}$ study region (Figure 2B). Charlotte is situated in the center of the Southern Piedmont province, a biologically diverse and productive ecoregion that still supports large areas of forest and farmland. Home to more than 2 million people (North Carolina Office of State Budget and Management [NCOSBM] 2010), the region's rolling landscape is connected via a high-speed interstate system and has some of the highest densities of secondary and tertiary road networks in the United States. The region holds few environmental obstacles for development, and with the exception of impounded river systems to the east and west, there are no geographic barriers. In this strong property rights state (Wang, Thill, and Meentemeyer 2012), planning is primarily implemented through zoning; alternative controls such as adequate public facility ordinances have not been supported by the state judiciary. Despite recent economic recession conditions, Charlotte-Mecklenburg and its ten surrounding North Carolina counties are projected to gain nearly 700,000 people by 2030 , a 30 percent increase in population (NCOSBM 2010).

\section{Remote Sensing of Land Change}

We developed an empirical understanding of trends in land change by tracking urban and rural development over four decadal time steps (1976, 1985, 1996, and 2006) from three data sources: moderate-resolution Landsat MSS and TM satellite imagery, aerial orthophotography, and high-resolution light detection and ranging data (LiDAR). We used three sequential procedures to classify remote sensing data into three terrestrial land cover classes (development, forest, and farmland) at each time step: (1) subpixel modeling of Landsat data into vegetation-impervious surface-soil (VIS) fraction components (Lee and Lathrop 2005; Gluch and Ridd 2010), (2) classification of developed and undeveloped land covers from the VIS fractions with manual correction using orthophotography, and (3) further discrimination of spectrally similar forest and farmland vegetation within the undeveloped class using vegetation structure data derived from LiDAR. We mapped patterns of land cover change ourselves because the study system contains numerous areas of low-density land cover types prone to misclassification by commonly used land cover data such as the National Land Cover Dataset (Irwin and Bockstael 2007).

In the first step, we used VIS modeling and unconstrained linear spectral unmixing analysis to produce fractional components representing the relative proportion of vegetation, impervious surfaces, and soil for each Landsat image pixel (Lee and Lathrop 2005). Image preprocessing included both radiometric calibration of image data to at-sensor reflectance and across-band brightness normalization (C. S. Wu 2004). We used aerial orthophotography to select training sites representing pure end members for green vegetation, impervious surfaces, and exposed soil. The spectral unmixing process generated representative fractional images of the region that were rescaled to sum to one.

Second, we used logistic regression to classify the continuous VIS fractions into developed or undeveloped categories based on interpretation of 550 points 
in concurrent 2006 orthophotography. The two-class system reduces the likelihood of error as compared to three or more classes (Pontius and Malizia 2004). We classified agricultural lands and industrial forests as undeveloped, whereas highly managed "green" areas, such as golf courses and irrigated lawns, were assigned to the developed class. We then used heads-up digitizing to correct obvious misclassifications.

Third, we further distinguished forest and farmland types of undeveloped land cover using LiDAR data collected in 2004. Our model of vegetation height derived from the first and last LiDAR returns clearly discriminated forests from farmlands (Singh et al. forthcoming). Within a geographic information system (GIS), we used the height model in overlay analysis to update the 1996 land cover maps under the reasonable assumption that forests in 2006 were also forested in 1996. We assessed map accuracy using concurrent high-resolution aerial photography. For each time step, we evaluated a total of 150 randomly located points for the presence of development per satellite image. Overall accuracy for classifications ranged from 78 percent (1976) to 86 percent (2006).

Our analysis of historical imagery revealed rapid and extensive conversions of agricultural and natural landscapes between 1976 and 2006. During the thirty-year period, more than 280,000 ha of forest and farmlands converted to developed land, increasing the total built environment to 24 percent of the nonwater area. Lands converted at a rate of 35 ha per day between 1985 and 1996 and 32.5 ha per day between 1996 and 2006.

\section{Development Potential Submodel (POTENTIAL)}

To build the multilevel statistical model, we developed a response variable based on conversions of undeveloped to developed lands identified from remote sensing between 1996 and 2006. Analysis revealed that this period (1996-2006) experienced robust yet slowing growth preceded by a decade (1985-1996) of rapid expansion. We assumed that factors driving development suitability during the more recent decade would also drive suitability for the period of projection. We generated a binary, developed-undeveloped response variable using a stratified-random sample of 1,450 grid cells distributed across the eleven-county study extent ( $n=848$ transitioning cells; $n=602$ forest and farmland cells). We excluded from analysis all water bodies and areas protected from development (e.g., no-build buffers, conservation areas). Prior to fitting the model, we selected a set of significant $(p<0.05)$ and uncorre-
Table 2. Results of generalized linear mixed model: Fixed effects including interaction between development pressure and land cover followed by random effects for intercept and development pressure which vary by county

\begin{tabular}{lrrc}
\hline Fixed effects & Estimate & SE & $p$ value \\
\hline Intercept $^{\mathrm{a}}$ & 0.39 & 0.25 & 0.12 \\
Development pressure (DP) $^{\mathrm{a}}$ & 0.27 & 0.05 & $<0.001$ \\
Distance to interchanges & -0.02 & 0.01 & 0.01 \\
Distance to roads & -0.52 & 0.09 & $<0.001$ \\
Land cover & -0.35 & 0.17 & 0.04 \\
$\quad$ Forest (1)/Farmland (0) & & & \\
DP: Land cover & 0.11 & 0.05 & 0.02 \\
\hline
\end{tabular}

Random effects

\begin{tabular}{lcc}
\hline County & Intercept & $\begin{array}{c}\text { Development } \\
\text { pressure }\end{array}$ \\
\hline Anson & -0.08 & 0.45 \\
Cabarrus & 1.18 & 0.26 \\
Catawba & 0.54 & 0.31 \\
Cleveland & -0.14 & 0.33 \\
Gaston & 0.17 & 0.11 \\
Iredell & 0.70 & 0.08 \\
Lincoln & 0.77 & 0.29 \\
Mecklenburg & 0.82 & 0.20 \\
Rowan & -0.01 & 0.33 \\
Stanly & -0.22 & 0.29 \\
Union & 0.68 & 0.24 \\
\hline
\end{tabular}

Note: $\mathrm{SE}=$ standard error.

${ }^{\mathrm{a}}$ Varies by county, see random effects.

lated predictors of change from our initial list of hypothesized site suitability variables (Table 1) using forward and backward stepwise regression techniques. We also tested for a hypothesized interaction between development pressure and land cover (forest vs. farmland). We included "county" as the group-level indicator in the multilevel model to account for spatially nonstationary processes inherent across jurisdictional boundaries. The varying intercept-varying slope model explained overall differences in development potential as well as variation in relationships between potential and the predictors among counties. Here, we allowed only the slope of the development pressure variable to differ by county (Table 2).

We used Laplace approximation, suitable for multilevel modeling with binary response variables (Bolker et al. 2009), to estimate model parameters with the lme4 package (Bates and Maechler 2009) in R Version 2.10.0 (R Development Core Team 2009). The probability, $p$, 
that an undeveloped cell, $i$, becomes developed is

$$
p_{i}=\frac{e^{s_{i}}}{1+e^{s_{i}}}
$$

where $s_{i}$ is the composite development potential for cell $i$ in Equation 1, which is a function of the original development potential $s_{i}^{\prime}$ and distance $d$. Further, the original development potential $s_{i}^{\prime}$ is a function of environmental, infrastructural, and socioeconomic predictor variables of site suitability (Table 1). Specifically, in this study, $s_{i}^{\prime}$ is described by:

$$
s_{i}^{\prime}=a_{j[\mathrm{i}]}+\sum_{h=1}^{n} \beta_{j[i] h} * x_{i h}+\beta_{j[i]} * p_{i}^{\prime}
$$

where, for the $i$ th undeveloped cell and varying across $j$ groups (i.e., the level), $a_{j[i]}$ is the intercept, $\beta_{j[i]}$ is the regression coefficient, $h$ is a predictor variable representing conditions in 1996, $n$ is the number of predictor variables, $x_{i h}$ is the value of $h$ at $i$, and $p_{i}^{\prime}$ is the dynamic development pressure variable (see Equation 2). We determined the value of the development pressure variable by running the statistical analysis for values of $\gamma$ ranging from 1 to 100 and choosing the value $(\gamma=$ 1.8) that resulted in peak model performance based on likelihood profile estimates (Hilborn and Mangel 1997; Meentemeyer et al. 2008).

Overall model results indicated that the probability of development was greatest in farmlands surrounded by high development pressure and close to roads and highway interchanges (Table 2). As development pressure increased, there was a shift toward greater probability of development in forested areas close to road networks. Because we implemented a multilevel model to establish these relationships, the effect of development pressure varies spatially with unique, county-level parameter estimates for $\beta$ (Table 2). We applied the most parsimonious multilevel model (Table 2) to the mapped predictor variables in the GIS to produce a spatially explicit surface of development potential for initiating simulations (POTENTIAL; Figure 3A).

\section{Land Demand Submodel (DEMAND)}

We projected future rates of per capita land consumption (DEMAND) based on relationships between trends in population growth and demand for development that occurred between 1976 and 2006 (Figure 3B). For each of our historical time steps (1976, 1985, 1996, and 2006), we obtained county-level population totals from the State Demographics Branch of the NCOSBM. We acquired annual projections of population growth by county through the year 2030 from the same source. For each of the eleven counties, we used ordinary least squares regression-allowing for linear or logarithmic relationships-to estimate a "best fit" model of population versus area of development (1976-2006) as mapped from our remote sensing of land change. We then used each regression equation to extrapolate per capita land consumption through 2030 based on future population projections (Figure $3 \mathrm{~B}$ ). Forecasts of land consumption provided by the submodel DEMAND drive the rate of development in the PGA submodel for the simulation of future land development.

\section{Calibration of the PGA}

We used empirical distributions of patch size and shape metrics (compactness, as defined later) of new development patterns identified in our analysis of 1996 and 2006 imagery as references to calibrate our model. We assumed that the factors driving spatial configuration of development events during this period would continue throughout the period of projection. Starting with 1996, we conducted simulations at one-year time steps, assuming that an equal number of cells converted into development each year.

To calibrate PGA's annual simulations of development events, we first derived simulated distributions of patch size and shape that, when accreted over ten years, closely matched observed patch metrics. We derived the patch size distribution for our simulation model $f_{\text {sim }}$ by converting the empirical distribution of patch size $f_{\text {obs }}$, using:

$$
f_{\text {sim }}(\text { psize })=\theta * f_{\text {obs }}(\text { psize })
$$

where $\theta$ is a discounted factor that varies between zero and one, and psize is the variable of patch size (Table 1 ). We compared a range of ten-year simulation outcomes generated by various discount factors and tuned $\theta$ to 0.6 to obtain reasonable agreement between simulated and observed patch size (Figure 4A).

The shape metric (noted as SHAPE) used in calibration was defined as:

$$
\text { SHAPE }=P_{k} / \min _{-} P_{k}
$$

where $P_{k}$ is the perimeter of patch $k$, and $\min P_{k}$ is the perimeter of a circle given the same patch area (see McGarigal et al. 2002). 
Figure 4. Calibration of FUTURES patch-growing algorithm (PGA). Frequency distributions for calibrated landscape show strong agreement between simulated and observed patch (A) size and (B) shape metrics.
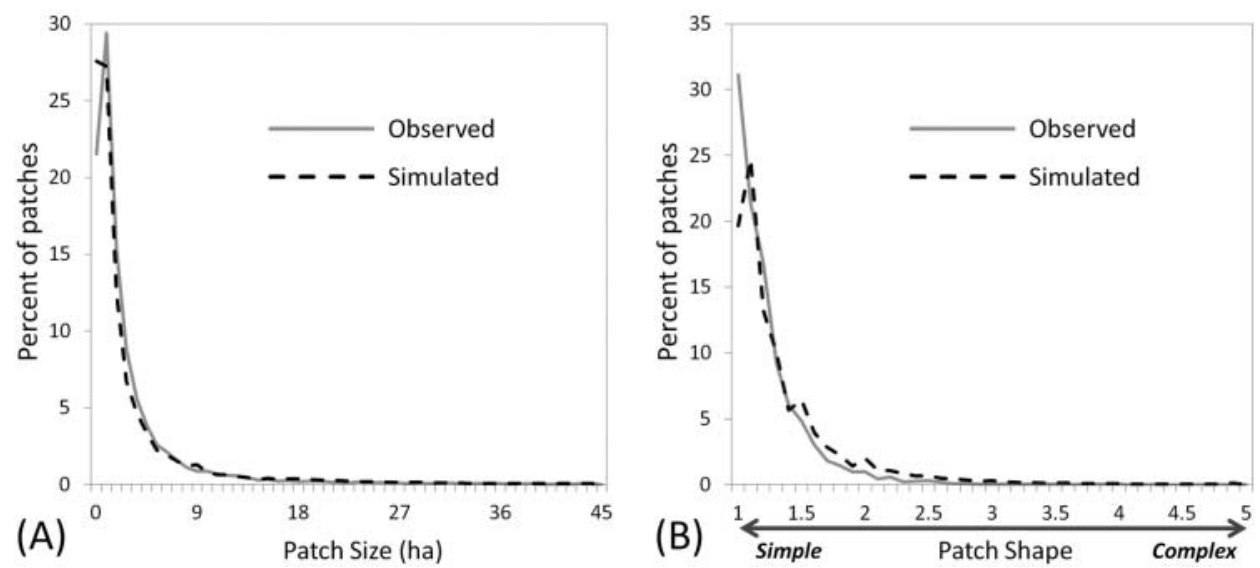

We analyzed the mean output of fifty stochastic realizations and iteratively adjusted the patch compactness parameter $\alpha$ (Equation 1) until the distribution of simulated and observed patch shape matched closely (Figure 4B). Comparison of histograms of the shape index between simulated and observed patterns was used to support shape calibration (Figure 4B). The range of the patch compactness parameter $\alpha$ was calibrated to $[0.32,0.48]$, where a uniform distribution was used to draw distributed values of $\alpha$ to generate alternative shape parameters for patches to be simulated. For this application, we reduced computational complexity by parameterizing PGA's patch-building capabilities using a representative region of the metropolitan area (Cabarrus County; Figure 2C), though FUTURES' multilevel structure allows patch characteristics to be calibrated separately for all levels in the model. The urban-rural continuum across Cabarrus County encompasses the range of patch characteristics across the study region (Figure 4).

\section{FUTURES Model Performance}

We applied the calibrated version of FUTURES to simulate land change between 1996 and 2006 in the eleven-county region and assessed its ability to simulate patterns of urban, suburban, and rural development. Because FUTURES aggregates cell-level change to produce patches of land change events, we evaluated the geographical variation of simulations-based on the mean of fifty stochastic model runs - using both cell- and patch-level diagnostics along an urban-rural gradient instituted by imposing a $6 \mathrm{~km} \times 6 \mathrm{~km}$ lattice over the study area (Figure 5A; Figure 5B for detail) and ranking each lattice block by percentage of developed lands as of 1996, hereafter referred to as the development density gradient.

We conducted model diagnostics recommended by Chen and Pontius (2010) with one modification: We partitioned null successes into eligible and ineligible categories to reflect heuristics that prevent FUTURES from simulating growth in developed areas (Figure 5). FUTURES simulated 9.2 percent change for the rurally biased study extent (Figure $5 \mathrm{C}$ ), whereas observed change was 8.3 percent. On average, hits (2.1 percent) and combined null successes ( 84.6 percent) constituted 86.7 percent of the landscape. Figure of merit, the measure of statistical agreement between observed and simulated change (Pontius et al. 2008), was 13.6 percent. Assessing simulated landscape composition relative to development density aggregated on the $6 \mathrm{~km} \times 6 \mathrm{~km}$ lattice revealed a relative evenness in correctness and error of simulated change except in the most rural areas (Figure 5D).

Evaluation of cell-based change revealed error due to quantity (1.2 percent) and error due to allocation (12.1 percent) totaling 13.3 percent of the landscape on average (Figure 6A). Distribution of these errors along the development density gradient indicates that FUTURES slightly overestimates development in rural areas and underestimates in more urban settings (Figure 6B). Our patch-level assessment of spatial structure first compared the area of observed patches to the area of simulated patches of new development, averaged by block. With respect to both the one-to-one line of perfect agreement and the development density gradient, results indicate a bias in model performance for overestimating patch area in more rural settings (Figures 7A, 7B, and $7 \mathrm{C}$ ). The number of patches constructed showed a stronger correspondence between observed and simulated with respect to the one-to-one line and along the 


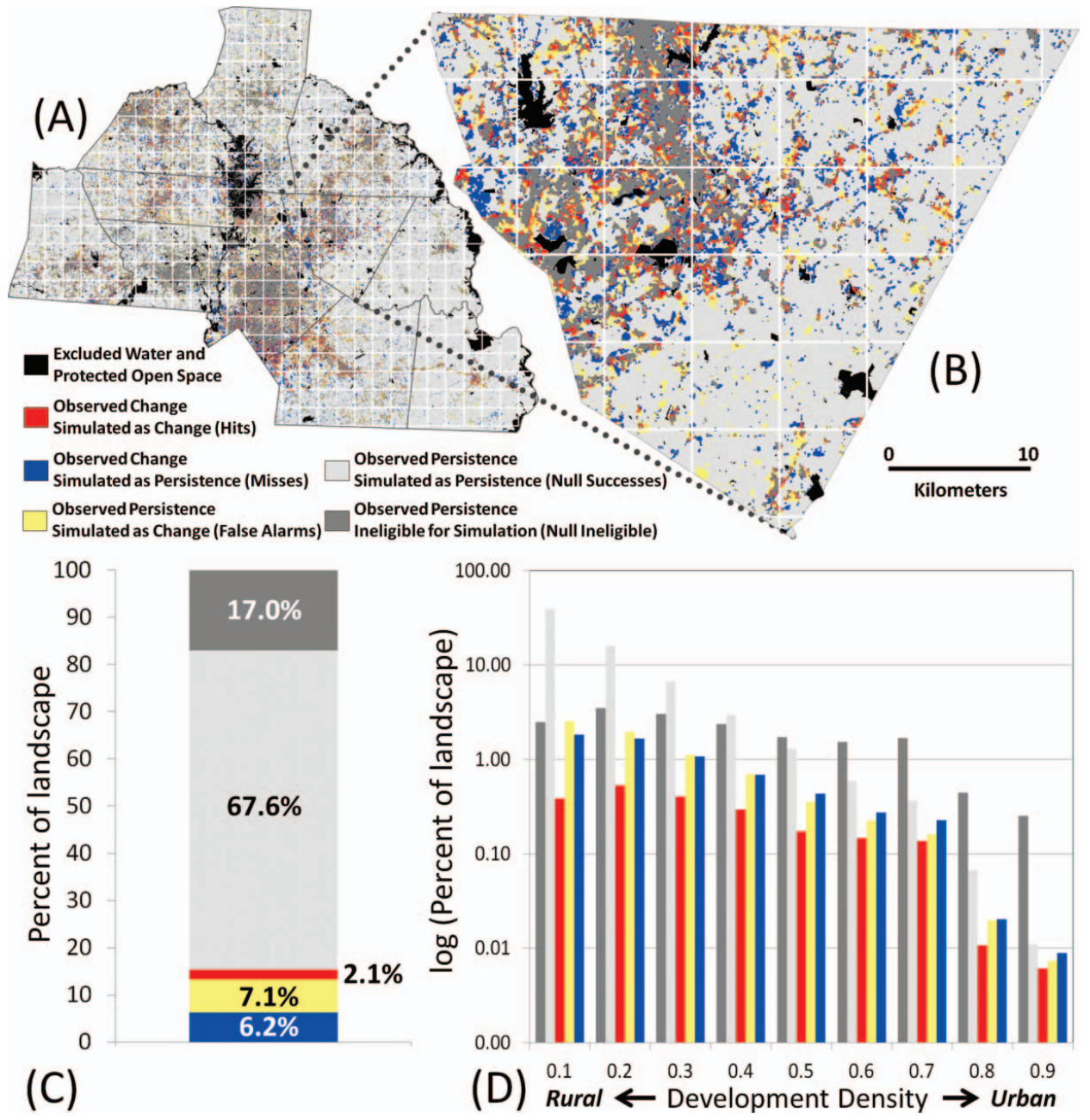

Figure 5. Cell-level model performance based on simulation successes and errors across study system. (A) Spatial distribution of successes and errors comparing 1996-2006 observed and simulated change. The $6 \times 6 \mathrm{~km}$ lattice (white grid) used to analyze successes and errors by block and along development density gradient. (B) Successes and errors in Cabarrus County. (C) Proportions of successes and errors for entire landscape. (D) Distribution of block-summarized successes and errors along development density gradient (bin interval of 0.1). Map legend also applies to (C) and (D) with the exception of excluded water and protected open space. (Color figure available online.) development density gradient. Mapped residuals corroborate these findings (Figures 7D, 7E, and 7F).

\section{Simulation Experiments}

Forest and agricultural landscapes along urbanexurban gradients are often highly fragmented, with compromised productivity and ecosystem function compared to their bucolic counterparts; nonetheless, these remnant landscapes are vital repositories of cultural practice, refuges of natural heritage and biodiversity, and essential providers of clean air, water, and open space (McDonnell and Pickett 1990; Bolund and Hunhammar 1999). Despite the recognition of these ecosystem services, policies designed to manage unsustainable growth have been largely ineffective (Anthony 2004; Howell-Moroney 2007). Researchers of coupled human-natural systems are increasingly recognizing the value of using land change models to ex- plore potential impacts of growth on future landscapes (B. L. Turner, Lambin, and Reenberg 2007). Inquiryand strategy-driven projections of long-term societal and environmental change allow stakeholders to test planning and policy interventions long before implementation (Alcamo 2008) and across large spatial scales that cross municipal boundaries and stakeholder priorities. Yet little is known about the efficacy of growth management approaches to minimizing fragmentation of natural areas due to a paucity of applied case histories and the challenge of simulating fragmented spatial structures as exemplified by parcel-based analyses by Irwin, Bell, and Geoghegan (2003) and Irwin and Bockstael (2004).

We used FUTURES to evaluate the emergence of landscape spatial structure in response to two hypothesized growth management approaches in the rapidly urbanizing Charlotte metropolitan region and compared those outcomes to projected patterns based on recent development trajectories. Our simulation 


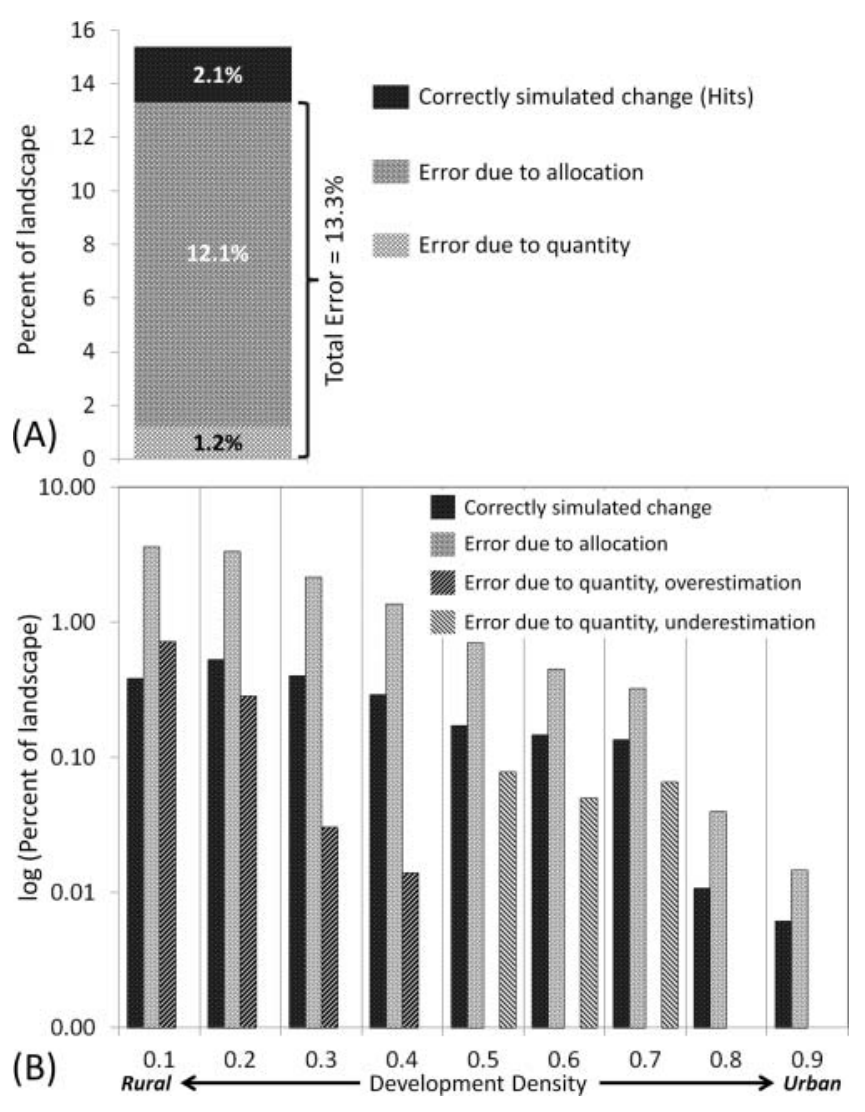

Figure 6. Cell-level model performance based on accuracy of simulated change (1996-2006) across study system. (A) Proportions of errors and correctly simulated change for entire landscape. (B) Distribution of errors and correctly simulated change along development density gradient (bin interval of 0.1 ). Overestimation indicates false alarms > misses; underestimation indicates false alarms $<$ misses. Missing bars indicate no error in category.

experiments were conducted over a twenty-five-year period (2006-2030) using the calibrated version of FUTURES where (1) the region continued the status quo trend of growth observed between 1996 and 2006; (2) per capita land consumption varied above and below rates observed prior to 2006 using the DEMAND submodel (Figure 3B); and (3) we transformed development suitability using the INCENTIVE parameter to examine the change in the distribution and spatial structure of new patches across the landscape (Figure 3C). At the end of each experiment, we quantified changes to the spatial structure of forest and farmland resources through 2030 using the landscape metrics software, FRAGSTATS (McGarigal et al. 2002), which aggregated pixels into patches based on a four-neighbor rule and measured the area, number, and shape complexity of new patches (Equation 6). We assumed stationarity in process during the projection period-that is, the simulation of new patches of development (patch size and patch shape) would closely emulate the observed size and shape characteristics of patches formed during the 1996 to 2006 historical time period (Figure 4) — to establish status quo benchmarks for comparison to alternative development outcomes.

\section{Benchmark: Historical Trajectory of Landscape Change}

To establish a benchmark, we first projected urban growth in the eleven-county region through 2030 based on the continuation of land consumption trends observed between 1996 and 2006. This period is noteworthy for Charlotte because the land grab that occurred in the previous decade (1985-1996) slowed from 35 ha per day to 32.5 ha per day, given similar economic conditions and a maturing of the land development market. During this period, immigration to the region remained strong and increased linearly (Figure 3B). Expansion of Charlotte's transportation beltway I-485 during this period lowered mean commute times to twenty-eight minutes but increased access to undeveloped lands (Charlotte Chamber of Commerce 2011).

FUTURES projected that continued growth trends will convert an additional 212,650 ha of forest and farmland by 2030, increasing developed land use from 24 percent to 41 percent of the nonwater landscape (see Figure $8 \mathrm{~A}$ for detailed map). Projections of the rate of development show a continuation of the slowing trend, from an average of 27 ha per day between 2007 and 2016 to 21 ha per day by 2030. Many undeveloped areas experience substantially more fragmentation: Forest remnants become smaller (9.7 ha vs. $17.8 \mathrm{ha}$ ), more numerous $(52,467$ vs. 38,602$)$, and slightly more complex in shape (1.24 vs. 1.22) in 2030 than in 2006, on average (see SQ values in Table 3). Farmland responds somewhat differently to projected growth: Patches become smaller on average ( 2.9 ha vs. 4.5 ha) but similar in number $(88,413$ vs. 90,000$)$ and shape $(1.22$ vs. 1.24).

\section{Landscape Response to Per Capita Land Consumption}

We simulated growth patterns over the benchmark period (1996-2030) using a range of per capita land consumption rates parameterized within the DEMAND submodel. High projections of land consumption assume that new populations demand more land per person than currently experienced; low projections assume 


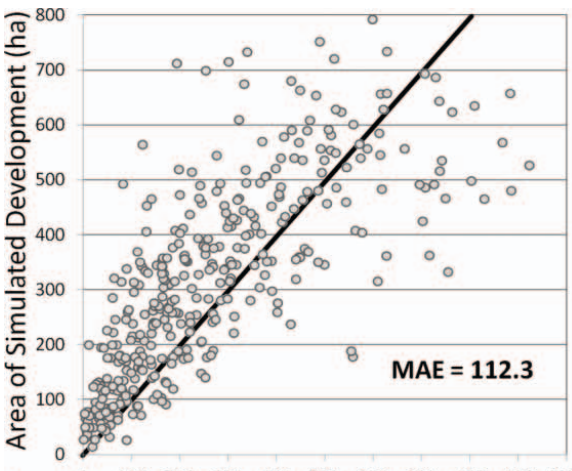

(A) $\begin{array}{rrrr}100 & 200 \quad 300 \quad 400 & 500600 \quad 700800900 \\ \text { Area of Observed Development (ha) }\end{array}$

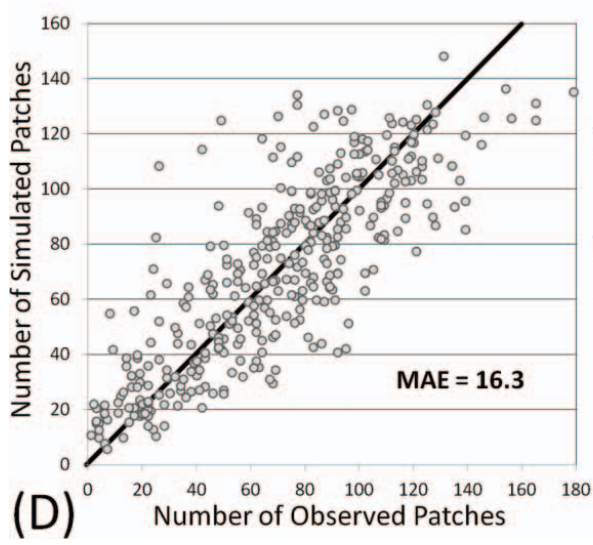

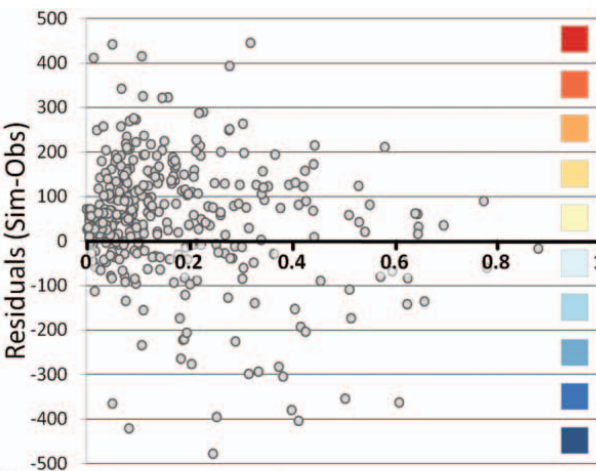

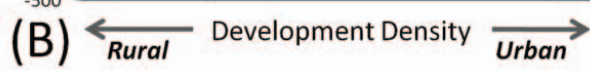

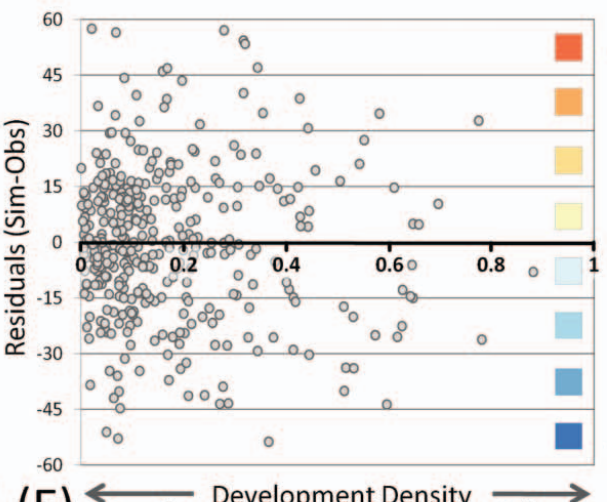

(E) $\leftarrow_{\text {Rural }}$ Development Density $\overrightarrow{\text { Urban }}$

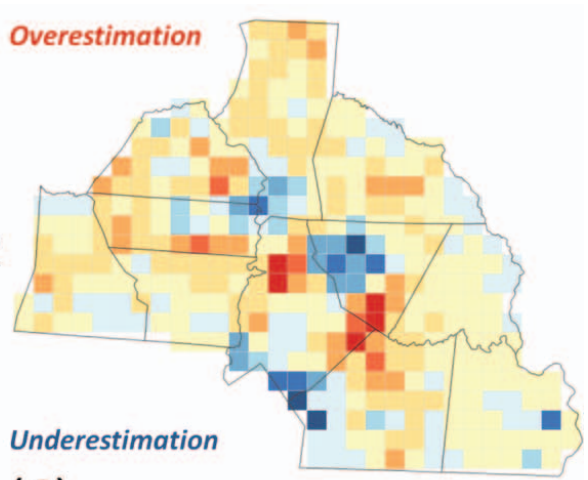

(C)

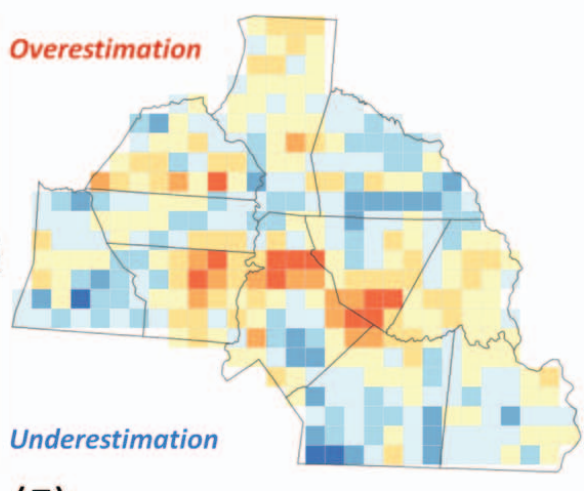

(F)

Figure 7. Patch-level model performance comparing 1996-2006 observed and simulated patch area and number of patches, summarized by blocks across study system. (A) Total patch area (ha) of observed and simulated development plotted along one-to-one line and with mean absolute error (MAE) reported. (B) Residuals of total area (ha) of development plotted along development density gradient and (C) spatial distribution of residuals indicate overestimates in North and East Charlotte and rural areas. (D) Number of observed and simulated patches of development plotted along one-to-one line and with MAE reported. (E) Residuals of number of patches of development plotted along development density gradient and (F) spatial distribution of residuals indicate over- and underestimation vary across region with overestimates in transitioning areas of North and East Charlotte. Blocks with $>50$ percent of area beyond study system boundary were excluded. (Color figure available online.)

each individual uses less land (Figure 3B). Treatments ranged from 40 percent below levels observed between 1996 and 2006 to 40 percent above (Table 3). We made changes to per capita land consumption at the county level and held all other factors constant, including development suitability and PGA parameterizations. For each treatment, we ran FUTURES fifty times to provide more reliable estimates of mean behavior. We conducted patch analyses for each simulation with average values reported.

Reducing per capita consumption by 40 percent, from an average of 0.80 ha per person to 0.48 ha per person, retained more than 38,500 ha of forest and 27,100 ha of farmland region-wide by 2030, conserving 19 percent of the total green space as compared to losses anticipated by the historical trend (Table 3 and Figure 8B). Reductions in consumption also minimized fragmenta- tion of forests as indicated by fewer patches and larger patch areas. Farmlands were also conserved with reductions in per capita consumption, but whereas patch area increased, the number of patches also increased (Table 3). Elevated levels of per capita consumption expectedly increased losses of forest and farmlands above the historical trends (Table 3 and Figure 8B).

\section{Impacts of INCENTIVE on Development Distribution}

We explored landscape responses to hypothesized growth management practices that reward or discourage the placement of new development by changing the relative attractiveness of undeveloped lands. Clustering new development near existing infrastructure has the potential to reduce service costs (Carruthers and 







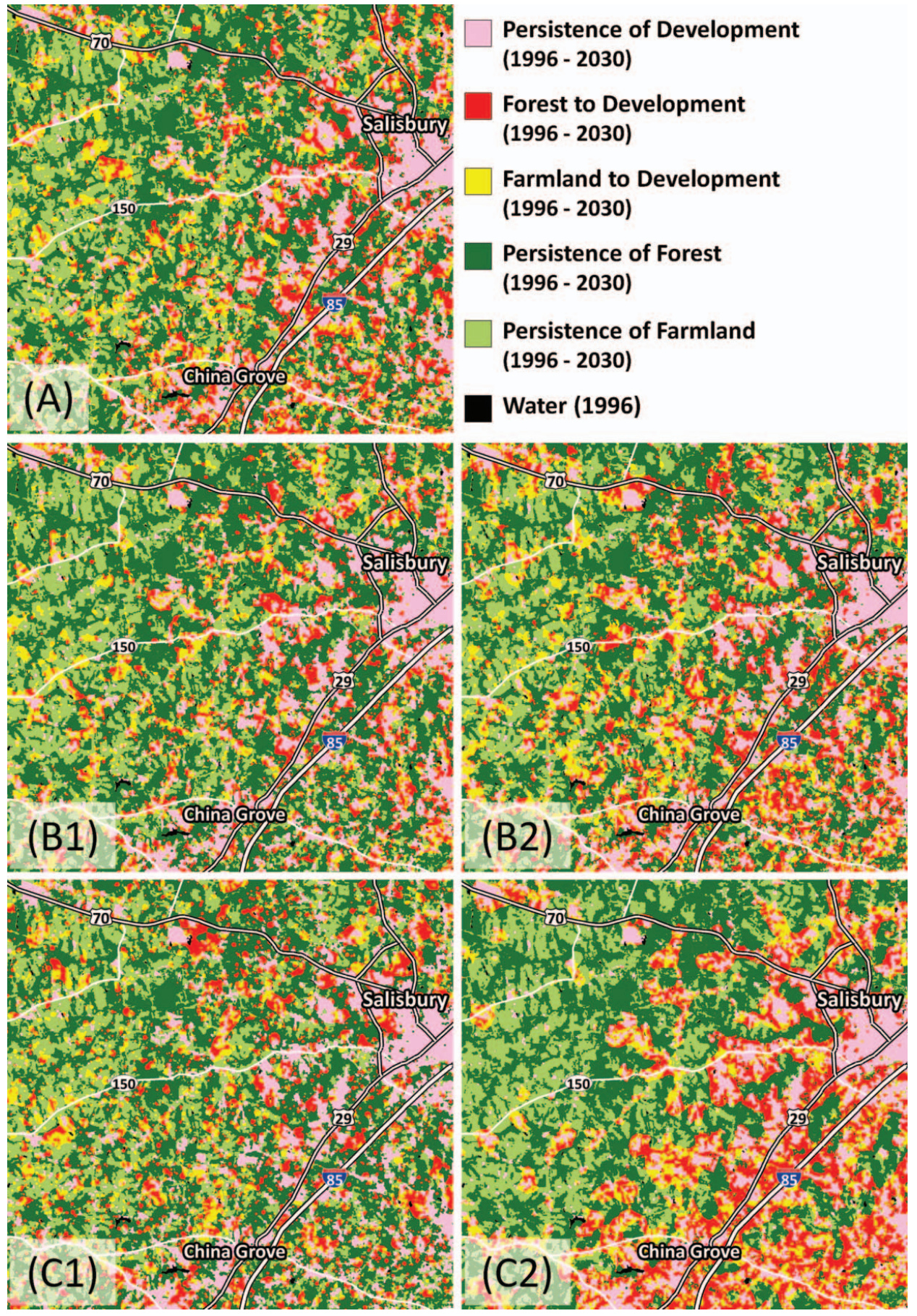

Figure 8. Detail views $(20 \mathrm{~km} \times$ $20 \mathrm{~km}$ region of Rowan County) of land change projections (1996-2030) based on three simulation experiments. (A) Experiment 1: Continuation of observed (1996-2006) land consumption trends (status quo). Experiment 2 (impacts of per capita land consumption [PCLC]): Development density treatments ranged from (B1) 40 percent reduction in PCLC below observed rates (1996-2006) to (B2) 40 percent increase in PCLC above observed rates. Experiment 3 (impacts of locational INCENTIVE): Development potential gradient varied by adjusting INCENTIVE in treatments ranging from (C1) 0.25 (low infill incentive, greater sprawl) to (C2) 4.0 (high infill incentive, greater infill). (Color figure available online.)
Ulfarsson 2003), ease congestion and pollution associated with vehicle emissions (U.S. Environmental Protection Agency [EPA] 2001), and conserve forests and farmlands by reducing disjunct or leapfrog development. In practice, development suitability could be altered through disincentives such as the establishment of "growth boundaries" beyond which municipalities restrict or deny provisioning of sewer and water sys- tems to new settlement or economic incentives such as priority funding areas (PFAs) that promote infill over greenfield development (Cohen 2002). We used the INCENTIVES parameter (Figure $3 \mathrm{C}$ ) as a simple regional proxy for varying POTENTIAL and evaluated landscape response to projected growth through the year 2030. INCENTIVE modifies the evenness of the empirically derived POTENTIAL development suitability 
surface, thereby changing the survival likelihood of patch-starting seeds, an effect that in turn modifies the distribution of patches. We applied five treatments ranging from 0.25 (sprawl), which flattened development suitability, to 4.0 (infill), which attenuated development suitability. We held all other factors constant, including population projections, per capita land consumption, and the PGA parameterizations. For each treatment, we ran FUTURES fifty times to characterize stochasticity of human agency in land change dynamics. We conducted patch analyses for each simulation with average values reported.

Simulations with lower INCENTIVE treatments resulted in diffuse growth (Figure 8C), with increased fragmentation indicated by more patches of development, forest, and farmland and reduced patch size for development and forest (Table 4). In contrast, simulations with higher INCENTIVE treatments increased the relative suitability of undeveloped areas near extant high suitability (e.g., areas with high development pressure and close to roads and highway interchanges), resulting in more compact urban growth (Figure 8C), which reduced fragmentation of forest and farmland when compared with projections of historical trends (Table 4 and Figure 8A). Although higher INCENTIVE treatments resulted in small changes $( \pm 1$ percent) in both forest and farmland relative to status quo historical growth, lower INCENTIVE values unexpectedly consumed forests while preserving farmlands, with forests losing 18,000 ha ( -3.6 percent) and farmlands retaining 4,400 ha $(6.2$ percent $)$ compared to the status quo historical trend (Table 4 and Figure 9).

\section{Discussion}

Societies structure landscapes in patterns that result from complex combinations of decision processes (Bürgi and Turner 2002), driving forces (Bürgi, Hersperger, and Schneeberger 2004), and chance (Pontius and Spencer 2005), the results of which are manifested as a continuum of conversion events that consume and fragment undeveloped lands. Over time these processes are reciprocally influenced by the structures they create and agglomerate to produce regional settlement patterns. Here we present a methodology that diminishes the fundamental land change modeling dichotomy, whether process drives pattern or pattern drives process, by first reconciling the arbitrary process entity (cell, or grain)

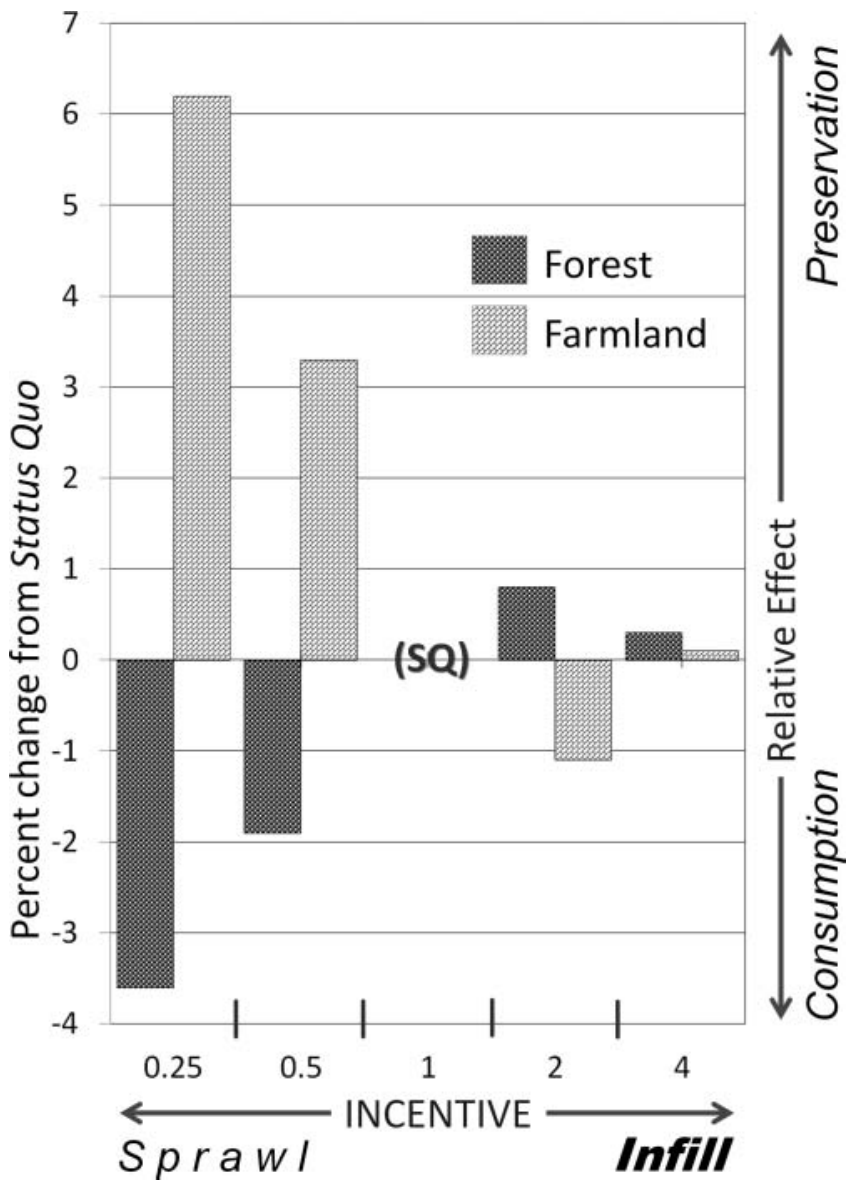

Figure 9. Differential response of forest and farmland to varying the locational INCENTIVE parameter.

with the structural object (land conversion events) and then building feedbacks between simulated structures and process-based transition probabilities. When applied to a series of hypothesized growth management treatments, FUTURES projected regional scenarios of land change that produced spatial structures of urbanization and fragmentation at landscape scales.

Multilevel structure is another characteristic that makes FUTURES appropriate for modeling land change dynamics at regional extents (Irwin, Jayaprakash, and Munroe 2009). Analysis of change at the subregional level (county) allowed us to account for socioeconomic and policy factors that vary across a region but that are not typically available as geospatial data (Fotheringham and Brunsdon 1999). The implementation of multilevel modeling also allowed relationships to diverge and vary spatially, rather than assuming stationarity across the entire metropolitan region (Gelman and Hill 2007). 


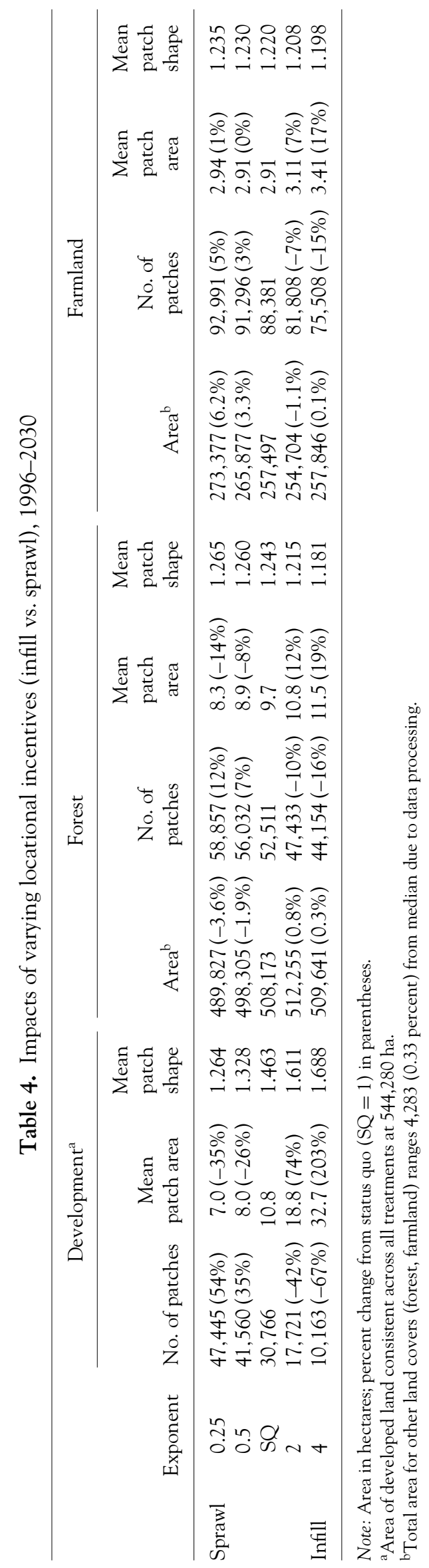




\section{Model Performance}

To explore the effects of growth along urban-rural gradients, FUTURES was designed to simulate leapfrog and exurban development objects in areas with low development potential while still converting undeveloped remnants in areas of high development suitability. These contrasting conversion events represent a modeling challenge in how best to allocate the limited number of prescribed transitions to simulate both urban and exurban growth with acceptable accuracy while maintaining generic heuristics that avoid overfitting a model. In analyzing error, relative evenness in correctness and error along the development density gradient indicated that FUTURES simulated new development in lowand high-suitability areas; in contrast, clumping (e.g., correctness biased toward high-potential areas) would have indicated that the spatial allocation of conversion events was flawed even if overall accuracy was higher as a result.

Validation diagnostics for the entire landscape indicated that FUTURES produced an overall accuracy of 86.7 percent, a high value due in part to the majority of the landscape being persistent, undeveloped land cover (Figure 5). The figure of merit, a measure of simulation accuracy, was 13.6 percent, a value consistent with other case studies where observed change is a rare event (e.g., less than 10 percent; Pontius et al. 2008). Analysis of error found 12.1 percent attributable to errors of allocation and 1.2 percent attributable to quantities prescribed by the DEMAND submodel (Figure 6A). Classification error for the interval (20 percent in 1996, 14 percent in 2006) could also account for a proportion of cell error (Pontius and Lippitt 2006). Relative evenness of error and correctness across the development density gradient (Figures 5D,6B) support FUTURES's applicability to simulating change over a range of regional contexts. Patch-level diagnostics aggregated from our regional lattice $(6 \mathrm{~km} \times 6 \mathrm{~km}$ blocks $)$ showed some rural bias between simulated and observed in terms of area of new patches of development (Figure 7A) and stronger correspondence in terms of the number of new patches of development (Figure 7D). When residuals of patch area (Figure 7B) and number of new patches (Figure 7E) are plotted along the development density gradient, we see that the study system is skewed toward rural land covers, but error exhibits relative homoscedasticity. Mapped residuals shows overestimate in rapidly transitioning areas of North and East Charlotte (Figures 7C, 7F).
Our application of FUTURES covered a large geographical extent $(174 \mathrm{~km} \times 140 \mathrm{~km}$; Figure 2), with land change dynamics represented as cell- and patchlevel mechanisms operating on a relatively fine spatial resolution $(30 \mathrm{~m} \times 30 \mathrm{~m})$. This spatial grain and extent made our application too computationally demanding for desktop computing environments to meet the required compute time and memory capacity (Tang and Wang 2009). We necessarily used high-performance computing to conduct multiple stochastic simulation runs distributed across multiple advanced computing processors with large memory configuration in a parallel manner (Wilkinson and Allen 2004). Smaller study extents for calibration and simplifying the equation for calculating development pressure at each time step are two options for overcoming computational barriers if a high-performance computing infrastructure is not accessible.

\section{Change in the Charlotte Region}

Since the mid-1980s, the Charlotte region has urbanized in disjoint, low-density patterns where over one third of an acre was developed for each regional occupant by 2006. Our DEMAND analyses revealed the alarming result that land conversions outpaced the doubling population. FUTURES projected additional losses of 212,650 ha of forested and agricultural land by the year 2030 if the trends exhibited between 1996 and 2006 persist. These trends are notable given the ongoing changes to infiltration zones, bioretention, and losses of evapotranspiration that have already led to the region's primary source of drinking water and power, the Catawba River Basin, being named America's most endangered river in 2008 by American Rivers (Hamilton, Kober, and Hewes 2008).

Charlotte's high and rising land consumption rates match those of megaregion sibling Atlanta but, in contrast, Charlotte's larger amount of remaining forests and farmlands suggest that it is still early enough in its growth trajectory to plan a more environmentally benign future. Our simulations of alternative futures of reduced landscape fragmentation and expansion of impervious surfaces illustrate that the region still has viable options. Despite growing interest in open space and "green" development, however, little change in policy is expected in the near term. North Carolina is a strong property rights state, with counties and municipalities limited to a few planning instruments, such as temporary building moratoria, adequate public facility 
ordinances (APFO), and zoning (Ott and Read 2006), the latter being routinely adjusted to landowners' wishes once development pressure is high enough.

\section{Simulation Experiments}

When fragmentation is understood as an emergent behavior generated by a complex system of multiple and disparate forcings, evolving feedbacks, and nonlinear trajectories of cause and effect, bottom-up approaches offer new tools into a seemingly intractable situation that confounds top-down, prescriptive approaches (Innes and Booher 1999). Given that current land use policy in the Charlotte region is unlikely to reduce fragmentation and its associated impacts, we explored the effects of two bottom-up treatments using simple global parameters that we view as proxies for market-based planning tools. Scenarios that lowered per capita land consumption, ostensibly through "upzoning" or density entitlements that permit builders to place more units per area, were revealed to conserve forest and farmland and reduce forest fragmentation (Table 3; Figure 8B). The dominant paradigm in the United States for conserving environmental and rural character, however, remains low-density zoning ordinances (L. Robinson, Newell, and Marzluff 2005), represented in the Charlotte region as status quo land consumption (Table 3). Ironically, our simulation results indicate that ordinances intended to reduce environmental impacts by limiting occupancy are likely to have the unwanted effect of increasing fragmentation.

We controlled the distribution of new development by changing the survival probabilities of seeding events using adjustments to the development suitability - analogous to the way policymakers influence construction starts using PFAs or APFOs. Simulated growth response to higher INCENTIVE values resulted in clustering development and a reduction in fragmentation of both forest and farmland while holding the absolute amount of converted land constant (Table 4; Figure 8C). Low INCENTIVE values, which made previously low- and mid-range development suitability areas relatively more attractive, led to more diffusive patterns of growth (Figure $8 \mathrm{C}$ ) that conserved farmland at the expense of forest (Table 4; Figure 9). This counterintuitive effect can be explained by agricultural abandonment (and subsequent forest regrowth) that often occurs at the frontier of urbanization (Foster 1992; Brown, Pijanowski, and Duh 2000). These findings suggest that locally contextualized or site-specific planning strategies might be needed to produce specific conservation outcomes.

Analysis of these land change scenarios provided an important avenue for the exploration of potential landscape-level impacts of future development on ecological communities and conservation priorities. Although no multijurisdictional body currently exists to implement these regional initiatives, we anticipate that our findings will nonetheless demonstrate FUTURES's capabilities to inform a range of stakeholders including governmental bodies charged with protecting human health and the environment (e.g., EPA, regional planning boards, environmental researchers).

\section{Conclusion}

FUTURES has two features that together make the model novel and useful for regional projections of urban growth and fragmentation. First, the patch-growing algorithm simulates the emergence of landscape spatial structure using a combination of field-based and object-based representations of land change. By bridging field-based and object-based representations, FUTURES scales up cell-level state transitions to form discrete patches of land conversion events, which in turn further agglomerate to produce multilevel patterns of growth and landscape fragmentation. Second, the multilevel modeling framework allows cross-scale drivers of land change to vary in space rather than produce a single solution for an entire region.

Our assessment of FUTURES's performance along an urban development density gradient, using both cell- and patch-based metrics, uniquely revealed spatial variation of simulation error and correctness, thereby informing the quantification of landscape fragmentation. The coupling of exogenous population demand for development with endogenous development suitability patterns promotes transparent interpretation of land change drivers in a system. Inquiry- and strategy-driven scenarios are made possible through FUTURES's adjustable parameters that control the spatial diffusion and shape of land change. These model characteristics support projections of long-term societal and environmental change that allow diverse stakeholders to test planning and policy interventions and build consensus toward goals. Application of FUTURES to the Charlotte metropolitan region illustrates how patch-based land change modeling can reference the spatial structure and multilevel nature of 
landscape changes with attention to size, shape, and distribution characteristics of fragmentation.

\section{Acknowledgments}

The authors gratefully acknowledge financial support from the Renaissance Computing Institute (RENCI), the National Science Foundation ULTRA-Ex program (BCS-0949170), and the Open Space Protection Collaborative. Nik J. Cunniffe was supported by the University of Cambridge. We thank K. Singh for providing LiDAR expertise and W. Feng, J. Deng, and A. Barge for assistance with programming. We also thank faculty, staff, and students affiliated with the Center for Applied Geographic Information Science at UNC Charlotte for constructive comments as this article was being developed. University Research Computing at UNC Charlotte and a National Science Foundation XSEDE supercomputing award (TG-SES090019) supported a portion of the computational resources needed to complete this work. We also thank Dr. Mei-Po Kwan and three anonymous reviewers for their insightful comments during revision of this article. Finally, first author Ross K. Meentemeyer acknowledges the equal role Douglas A. Shoemaker played in the conceptualization of FUTURES and writing of this article.

\section{References}

Aguilera, F., L. M. Valenzuela, and A. Botequilha-Leitão. 2011. Landscape metrics in the analysis of urban land use patterns: A case study in a Spanish metropolitan area. Landscape and Urban Planning 99 (3-4): 226-38.

Alberti, M. 2005. The effects of urban patterns on ecosystem function. International Regional Science Review 28 (2): 168-92.

- 2010. Maintaining ecological integrity and sustaining ecosystem function in urban areas. Current Opinion in Environmental Sustainability 2 (3): 178-84.

Alcamo, J. 2008. Environmental futures: The practice of environmental scenario analysis. Amsterdam: Elsevier.

Anthony, J. 2004. Do state growth management regulations reduce sprawl? Urban Affairs Review 39:376-97.

Arnfield, A. J. 2003. Two decades of urban climate research: A review of turbulence, exchanges of energy and water, and the urban heat island. International Journal of Climatology 23 (1): 1-26.

Arnold, C. L., and C. J. Gibbons. 1996. Impervious surface coverage: The emergence of a key environmental indicator. Journal of the American Planning Association 62 (2): 243-58.

Bates, D., and M. Maechler. 2009. Ime4: Linear mixed-effects models using S4 classes. R package version 0.99937532. http://CRAN.R-project.org/package=lme4 (last accessed 14 March 2012).
Berke, P. R., D. R. Godschalk, and E. J. Kaiser, with D. A. Rodriguez. 2006. Urban land use planning. 5th ed. Champaign: Illinois Press.

Bolker, B. M., M. E. Brooks, C. J. Clark, S. W. Geange, J. R. Poulsen, M. H. H. Stevens, and J. S. S. White. 2009. Generalized linear mixed models: A practical guide for ecology and evolution. Trends in Ecology $\mathcal{E}$ Evolution 24 (3): 127-35.

Bolund, P., and S. Hunhammar. 1999. Ecosystem services in urban areas. Ecological Economics 29:293-301.

Brown, D. G., P. Goovaerts, A. Burnicki, and M. Li. 2002. Stochastic simulation of land-cover change using geostatistics and generalized additive models. Photogrammetric Engineering 83 Remote Sensing 68:1051-61.

Brown, D. G., K. M. Johnson, T. R. Loveland, and D. M. Theobald. 2005. Rural land-use trends in the conterminous United States, 1950-2000. Ecological Applications 15 (6): 1851-63.

Brown, D. G., S. Page, R. Riolo, M. Zellner, and W. Rand. 2005. Path dependence and the validation of agentbased spatial models of land use. International Journal of Geographical Information Science 19 (2): 153-74.

Brown, D. G., B. C. Pijanowski, and J. D. Duh. 2000. Modeling the relationships between land use and land cover on private lands in the Upper Midwest, USA. Journal of Environmental Management 59:247-63.

Bürgi, M., A. Hersperger, and N. Schneeberger. 2004. Driving forces of landscape change-Current and new directions. Landscape Ecology 19:857-68.

Bürgi, M., and M. G. Turner. 2002. Factors and processes shaping land cover and land cover changes along the Wisconsin River. Ecosystems 5:184-201.

Carruthers, J. I., and G. F. Ulfarsson. 2003. Urban sprawl and the cost of public services. Environment and Planning $B$ : Planning and Design 30:503-22.

Charlotte Chamber of Commerce. 2011. Charlotte drive times. Charlotte, NC: Charlotte Chamber of Commerce.

Chen, H., and R. G. Pontius, Jr. 2010. Diagnostic tools to evaluate a spatial land change projection along a gradient of an explanatory variable. Landscape Ecology 25:1319-31.

Church, R. L., R. A. Gerrard, M. Gilpin, and P. Stine. 2003. Constructing cell-based habitat patches useful in conservation planning. Annals of the Association of American Geographers 93:814-27.

Cohen, J. R. 2002. Maryland's "smart growth": Using incentive to combat sprawl. In Urban sprawl: Causes, consequences and policy responses, ed. G. D. Squires, 293-324. Washington, DC: The Urban Institute Press.

Damschen, E. I., L. A. Brudvig, N. M. Haddad, D. J. Levey, J. L. Orrock, and J. J. Tewksbury. 2008. The movement ecology and dynamics of plant communities in fragmented landscapes. Proceedings of the National Academy of Sciences 105 (49): 19078-83.

Downs, A. 2005. Smart growth: Why we discuss it more than we do it. Journal of the American Planning Association 71 (4): 367-78.

Ewing, R., R. Pendall, and D. Chen. 2002. Measuring sprawl and its impacts. Washington, DC: Smart Growth America.

Florida, R., T. Gulden, and C. Mellander. 2008. The rise of the mega-region. Cambridge Journal of Regions, Economy and Society 1:459-76. 
Foster, D. R. 1992. Land-use history (1730-1990) and vegetation dynamics in central New England, USA. Journal of Ecology 80:753-72.

Fotheringham, A. S., and C. Brunsdon. 1999. Local forms of spatial analysis. Geographical Analysis 31:340-58.

Gagné, S. A., and L. Fahrig. 2011. Do birds and beetles show similar responses to urbanization? Ecological Applications 21:2297-2312.

García, A. M., I. Santé, R. Crecente, and D. Miranda. 2011. An analysis of the effect of the stochastic component of urban cellular automata models. Computers, Environment and Urban Systems 35:289-96.

Gelman, A., and J. Hill. 2007. Data analysis using regression and multilevel/hierarchical models. Cambridge, UK: Cambridge University Press.

Gluch, R. M., and M. K. Ridd. 2010. The V-I-S model: Quantifying the urban environment. In Remote sensing of urban and suburban areas, ed. T. Rashed and C. Jurgens, 85-116. New York: Springer.

Hamilton, H., A. Kober, and W. Hewes. 2008. America's most endangered rivers: 2008 edition. Washington, DC: American Rivers.

Herold, M., H. Couclelis, and K. Clarke. 2005. The role of spatial metrics in the analysis and modeling of urban land use change. Computers, Environment and Urban Systems 29 (4): 369-99.

Hilborn, R., and M. Mangel. 1997. The ecological detective: Confronting models with data. Princeton, NJ: Princeton University Press.

Howell-Moroney, M. 2007. Studying the effects of the intensity of US state growth management approaches on land development outcomes. Urban Studies 44:216378.

Innes, J. E., and D. E. Booher. 1999. Consensus building and complex adaptive systems. Journal of the American Planning Association 65:412-23.

Irwin, E. G., K. P. Bell, and J. Geoghegan. 2003. Modeling and managing urban growth at the rural-urban fringe: A parcel-level model of residential land use change. Agricultural and Resource Economics Review 32:83102.

Irwin, E. G., and N. E. Bockstael. 2004. Land use externalities, open space preservation, and urban sprawl. Regional Science and Urban Economics 34:705-25.

- 2007. The evolution of urban sprawl: Evidence of spatial heterogeneity and increasing land fragmentation. Proceedings of the National Academy of Sciences of the United States of America 104 (52): 20672-77.

Irwin, E. G., C. Jayaprakash, and D. K. Munroe. 2009. Towards a comprehensive framework for modeling urban spatial dynamics. Landscape Ecology 24:1223-36.

Jantz, C. A., and S. J. Goetz. 2005. Analysis of scale dependencies in an urban land-use-change model. International Journal of Geographical Information Science 19:217-41.

Jenerette, G. D., and J. G. Wu. 2001. Analysis and simulation of land-use change in the central Arizona-Phoenix region, USA. Landscape Ecology 16:611-26.

Jones, K., and C. Duncan. 1996. People and places: The multilevel model as a general framework for the quantitative analysis of geographical data. In Spatial analysis: Modeling in a GIS environment, ed. P. Longley and M. Batty, 80-104. New York: Wiley.
Lee, S., and R. G. Lathrop, Jr. 2005. Sub-pixel estimation of urban land cover components with linear mixture model analysis and Landsat Thematic Mapper imagery. International Journal of Remote Sensing 26 (22): 48854905.

Li, X., Q. Yang, and X. Liu. 2008. Discovering and evaluating urban signatures for simulating compact development using cellular automata. Landscape and Urban Planning 86:177-86.

Lovell, S. T., and D. M. Johnston. 2009. Designing landscapes for performance based on emerging principles in landscape ecology. Ecology and Society 14 (1): 44. http://www.ecologyandsociety.org/vol14/iss1/art44/ (last accessed 31 July 2012).

McDonnell, M., and S. Pickett. 1990. Ecosystem structure and function along urban-rural gradients: An unexploited opportunity for ecology. Ecology 71:1232-37.

McGarigal, K., S. A. Cushman, M. C. Neel, and E. Ene. 2002. FRAGSTATS: Spatial pattern analysis program for categorical maps. Amherst: University of Massachusetts.

Meentemeyer, R. K., B. L. Anacker, W. Mark, and D. M. Rizzo. 2008. Early detection of emerging forest disease using dispersal estimation and ecological niche modeling. Ecological Applications 18 (2): 377-90.

Munroe, D. K., and D. Müller. 2007. Issues in spatially explicit statistical land-use/cover change (LUCC) models: Examples from western Honduras and the central highlands of Vietnam. Land Use Policy 24:521-30.

North Carolina Office of State Budget and Management. (NCOSBM). 2010. County/state population projections. North Carolina Office of State Budget and Management, State Demographics Branch, Charlotte, NC. http://www.osbm.state.nc.us/ncosbm/facts_ and_figures/socioeconomic_data/population_estimates/ county_projections.shtm (last accessed 26 April 2012).

Ott, S. H., and D. C. Read. 2006. Adequate public facilities ordinances in North Carolina: A legal review. Working paper, Center for Real Estate at UNC Charlotte, Charlotte, NC.

Overmars, K. P., and P. H. Verburg. 2006. Multilevel modelling of land use from field to village level in the Philippines. Agricultural System 89:435-56.

Pan, W. K. Y., and R. E. Bilsborrow. 2005. The use of a multilevel statistical model to analyze factors influencing land use: A study of the Ecuadorian Amazon. Global and Planetary Change 47:232-52.

Pontius, R. G., Jr., W. Boersma, J. C. Castella, K. Clarke, T.deNijs, C. Dietzel, Z. Duan, et al. 2008. Comparing the input, output, and validation maps for several models of land change. Annals of Regional Science 42:11-37.

Pontius, R. G., Jr., J. D. Cornell, and C. A. S. Hall. 2001. Modeling the spatial pattern of land-use change with GEOMOD2: Application and validation for Costa Rica. Agriculture Ecosystems $\mathcal{E}$ Environment 85 (1-3): 191-203.

Pontius, R. G., Jr., and C. D. Lippitt. 2006. Can error explain map differences over time? Cartography and Geographic Information Science 33 (2): 159-71.

Pontius, R. G., Jr., and N. R. Malizia. 2004. Effect of category aggregation on map comparison. Geographic Information Science, Lecture Notes in Computer Science 3234: 251-68. 
Pontius, R. G., Jr., and J. Spencer. 2005. Uncertainty in extrapolations of predictive land-change models. Environment and Planning B 32:211-30.

Radeloff, V. C., R. B. Hammer, and S. I. Stewart. 2005. Rural and suburban sprawl in the US Midwest from 1940 to 2000 and its relation to forest fragmentation. Conservation Biology 19 (3): 793-805.

R Development Core Team. 2009. R: A language and environment for statistical computing. Vienna: R Foundation for Statistical Computing. http://www.r-project.org (last accessed 20 April 2012).

Robinson, D. T., D. G. Brown, and W. S. Currie. 2009. Modelling carbon storage in highly fragmented and human-dominated landscapes: Linking land-cover patterns and ecosystem models. Ecological Modelling 220 (9-10): 1325-38.

Robinson, L., J. P. Newell, and J. M. Marzluff. 2005. Twentyfive years of sprawl in the Seattle region: Growth management responses and implications for conservation. Landscape and Urban Planning 71:51-72.

Singh, K., J. B. Vogler, D. A. Shoemaker, and R. K. Meentemeyer. Forthcoming. LiDAR-Landsat data fusion for large-area assessment of urban land cover: Balancing spatial resolution, data volume, and mapping accuracy. ISPRS Journal of Photogrammetry and Remote Sensing.

Sohl, T. L., T. R. Loveland, B. M. Sleeter, K. L. Sayler, and C. A. Barnes. 2010. Addressing foundational elements of regional land-use change forecasting. Landscape Ecology 25:233-47.

Tang, W., and S. Wang. 2009. HPABM: A hierarchical parallel simulation framework for spatially-explicit agentbased models. Transactions in GIS 13:315-33.

Turner, B. L., II, E. F. Lambin, and A. Reenberg. 2007. The emergence of land change science for global environmental change and sustainability. Proceedings of the $\mathrm{Na}$ tional Academy of Sciences 104:20666-71.

Turner, M. G. 1989. Landscape ecology-The effect of pattern on process. Annual Review of Ecology and Systematics 20:171-97.

United Nations Population Fund. 2007. The state of the world population 2007: Unleashing the potential for urban growth. New York: United Nations Population Fund.
U.S. Environmental Protection Agency (EPA). 2001. Our built and natural environments: A technical review of the interactions between land use, transportation, and environmental policy. Report EPA 231-R-01-002, U.S. Environmental Protection Agency, Washington, DC.

Verburg, P. H., and K. Overmars. 2009. Combining top-down and bottom-up dynamics in land use modeling: Exploring the future of abandoned farmlands in Europe with the Dyna-CLUE model. Landscape Ecology 24 (9): 116781.

Verburg, P. H., P. P. Schot, M. J. Dijst, and A. Veldkamp. 2004. Land use change modelling: Current practice and research priorities. GeoJournal 61:309-24.

Wackernagel, M., L. Onisto, P. Bello, A. C. Linares, I. S. L. Falfan, J. M. Garcia, A. I. S. Guerrero, and M. G. S. Guerrero. 1999. National natural capital accounting with the ecological footprint concept. Ecological Economics 29 (3): $375-90$

Wang, C., J.-C. Thill, and R. K. Meentemeyer. 2012. Estimating the demand for public open space: Evidence from North Carolina municipalities. Papers in Regional Science 91:219-32.

Weathers, K. C., M. L. Cadenasso, and S. T. A. Pickett. 2001. Forest edges as nutrient and pollutant concentrators: Potential synergisms between fragmentation, forest canopies, and the atmosphere. Conservation Biology 15 (6): 1506-14.

Wilkinson, B., and M. Allen. 2004. Parallel programming. Upper Saddle River, NJ: Prentice Hall.

With, K. A. 2002. The landscape ecology of invasive spread. Conservation Biology 16 (5): 1192-1203.

Wu, C. S. 2004. Normalized spectral mixture analysis for monitoring urban composition using ETM plus imagery. Remote Sensing of Environment 93 (4): 480-92.

Wu, F. 2002. Calibration of stochastic cellular automata: The application to rural-urban land conversions. International Journal of Geographical Information Science 16:795-818.

Yeh, A. G.-O., and X. Li. 2006. Errors and uncertainties in urban cellular automata. Computers, Environment and Urban Systems 30:10-28.

Correspondence: Department of Geography and Earth Sciences, University of North Carolina, 9201 University City Blvd, Charlotte, NC 28223, e-mail: rkmeente@uncc.edu (Meentemeyer); WenwuTang@uncc.edu (Tang); mdorning@uncc.edu (Dorning); John.Vogler@uncc.edu (Vogler); D.Shoemaker@uncc.edu (Shoemaker); Department of Plant Sciences, University of Cambridge, Cambridge, CB2 3EA, UK, e-mail: njc1001@cam.ac.uk (Cunniffe). 